\title{
Using structured decision making with landowners to address private forest management and parcelization: balancing multiple objectives and incorporating uncertainty
}

\author{
$\underline{\text { Paige F. B. Ferguson }}^{1,2}, \underline{\text { Michael J. Conrov }}^{2}, \underline{\text { John F. Chamblee }}^{3}$ and Jeffrey Hepinstall-Cymerman $^{2}$
}

\begin{abstract}
Parcelization and forest fragmentation are of concern for ecological, economic, and social reasons. Efforts to keep large, private forests intact may be supported by a decision-making process that incorporates landowners' objectives and uncertainty. We used structured decision making (SDM) with owners of large, private forests in Macon County, North Carolina. Macon County has little land use regulation and a history of discordant, ineffective attempts to address land use and development. We worked with landowners to define their objectives, identify decision options for forest management, build a Bayesian decision network to predict the outcomes of decisions, and determine the optimal and least-desirable decision options. The optimal forest management options for an average, large, forested property (30 ha property with 22 ha of forest) in Macon County was crown-thinning timber harvest under the Present-Use Value program, in which enrolled property is taxed at the present-use value (growing timber for commercial harvest) rather than full market value. The least-desirable forest management actions were selling 1 ha and personal use of the forest (e.g., trails, firewood) with or without a conservation easement. Landowners reported that they enjoyed participating in the project $(85 \%)$ and would reconsider what they are currently doing to manage their forest $(69 \%)$. The decision that landowners initially thought would best meet their objectives did not match results from the decision network. This highlights the usefulness of SDM, which typically has been applied to decision problems involving public resources.
\end{abstract}

Key Words: Bayesian decision network; conservation easement; decision analysis; forestry; fragmentation; heritage; present-use value; sustainability; timber harvest

\section{INTRODUCTION}

\section{The problem: parcelization and forest fragmentation}

In the 1920s, the amount of forest cover in the United States stabilized after many decades of declines, but forest fragmentation has been ongoing since the early 1900s (Sampson and DeCoster 2000, Best 2002). Also, the rate and extent of parcelization have increased in recent decades (DeCoster 1998, Best 2002). Parcelization is the division of a larger tract with a single owner into multiple, smaller parcels with multiple owners (Best 2002, Ko and He 2011). As a result of parcelization, the average parcel size decreases and the number of landowners increases (Kendra and Hull 2005, Ko and He 2011). During parcelization, forests are frequently fragmented (Best 2002). Fragmentation is the division of contiguous forest into discrete patches. These smaller patches often exhibit greater isolation, less interior habitat, and fewer ecosystem services (Groom et al. 1999, Best 2002). Parcelization can also change local economies (Harper et al. 1990). Smaller parcels may not be economically viable for timber production because of the economies of scale (Mehmood and Zhang 2001), so regional wood supplies may decrease (Wear et al. 1999), landowners may not be able to depend on this traditional source of income, and further parcelization may result (Ko and He 2011). Parcelization can also lead to further development and the conversion of previously forested land into more intense land uses, particularly residential subdivisions (Mehmood and Zhang 2001, Best 2002, Gobster and Rickenbach 2004). Finally, parcelization is associated with changes in social dynamics (Rickenback and Gobster 2003). As the number and density of landowners increase, the community experiences more diverse objectives and values (Egan and Luloff 2000, Smith and Krannich 2000, Mehmood and Zhang 2001). As the community changes, residents may experience a loss of community identity and sense of place (Cumming and Norwood 2012).

To manage parcelization, it is important to understand how owners of large, forested properties make decisions and to understand the objectives behind their decisions. If reducing parcelization is desired, ways to keep large properties intact that compliment landowners' objectives should be identified (Best 2002). Previous studies have found that landowners may consider parcelization because of the expense of taxes, because they can make a profit when urbanization of rural areas leads to property value increases, or when they inherit property but lack the means or interest to manage it (DeCoster 1998, Mehmood and Zhang 2001, Best 2002). The roles of finances and maintenance in parcelization are evident in the literature. If associated objectives can be met, landowners may be less likely to parcelize. Because many modern forestland owners have diverse objectives and may face increasing pressure to parcelize, landowners and forest management professionals may benefit from new approaches to forest management decision making (Kendra and Hull 2005).

We propose structured decision making (SDM) as a process that can enhance the sustainability of private forests by helping landowners identify decision options that are most likely to result in outcomes that meet objectives related to forest sustainability. The SDM procedure accomplishes this through (1) identifying landowners' multiple objectives and their relative importance and (2) modeling the probability of different outcomes following each decision option.

${ }^{1}$ Department of Biological Sciences, University of Alabama, ${ }^{2}$ Warnell School of Forestry and Natural Resources, University of Georgia,

${ }^{3}$ Department of Anthropology, University of Georgia 


\section{Approach: structured decision making with forestland owners}

SDM is based on decision analysis, the use of quantitative methods to evaluate decision options (Keeney 1992, Clemen 1996, Gregory et al. 2012, Conroy and Peterson 2013). The SDM approach is beneficial because it balances multiple objectives given constraints and uncertainty, and it recognizes the distinction between value-based information and technical information while explicitly integrating both (Gregory and Keeney 2002, Wilson and McDaniels 2007, Conroy et al. 2008). In the SDM process, the objectives and values of decision makers are included in analyses, but there is no attempt to change decision makers' objectives or values. Decisions made through a process that explicitly defines objectives, weights conflicting objectives, and incorporates uncertainty are expected to produce desirable outcomes more often than decisions made less systematically (Conroy and Peterson 2013).

The main components of SDM are a definition of the decision problem, objectives based on values, attributes to make objectives measurable, decision options that could help achieve objectives, one or more models to describe the expected outcomes of decisions, and a method to evaluate the degree to which each decision is expected to fulfill objectives (Conroy et al. 2008, Irwin et al. 2011). These components are developed through an iterative process in which stakeholders provide input and facilitators synthesize information while attempting to remain value neutral (Miller et al. 2010, Raymond et al. 2010, Irwin et al. 2011). We conducted a SDM project focused on the management of large private forests in Macon County, North Carolina, USA, that involved a series of workshops with forestland owners.

\section{Study site: Macon County, North Carolina, USA}

We focused on forestland owners in Macon County, North Carolina, USA, because Macon County has experienced high rates of residential development, there is a history of conflict over land use regulations, and the region is one of the most biodiverse in North America (Barnes 1991, Gragson and Bolstad 2006). The growth in Macon County has been associated with the amenitydriven development seen throughout the southern Appalachian region. During the 1990s, this region experienced $18 \%$ growth in population (Pollard 2005).

Many Macon County landowners think rapid growth is detrimental, but there has not been agreement about an appropriate response (Gragson and Bolstad 2006, Cho et al. 2009, Cumming and Norwood 2012). There have been attempts to pass land use regulations in Macon County throughout the past 30 years, but they have largely failed (Cumming and Norwood 2012). Consequently, many land use decisions are made by individual landowners. Macon County is not unique in experiencing confrontational and eventually stalled land use decision making, and this phenomenon has been attributed to the lack of effective opportunities for citizens to express their perspectives, consider potential options, and learn from each other in a respectful and productive setting (Lando 2003, Stewart et al. 2004, Cumming and Norwood 2012).

\section{Research statement}

The purpose of this study is to illustrate how SDM can assist landowners with land use decision making. This is important to demonstrate for a community where attempts at land use regulation have been unproductive and because SDM has a more extensive history of application to decisions that involve multiple stakeholders and a common resource. We describe the SDM process with landowners and discuss advantages and challenges of using SDM in this context. In Macon County, we applied SDM to the question of forest management on large parcels (30-ha property with 22 ha of forest), and we present the forest management options that were identified as optimal and least desirable. Additionally, we consider landowners' perception of the SDM process and the potential for land trusts and land use planners to benefit from SDM.

\section{METHODS}

\section{Decision context}

The goal of the SDM project in Macon County was to address the question "What can you do to your forest to maximize the achievement of your land use objectives?" with owners of large, forested properties (at least 20 ha in total area with at least 4 ha of forest). Throughout the project, we asked landowners for their personal perspectives, but the analysis was not intended to apply to a specific property. Rather, we evaluated decision options for an average, large, forested property in Macon County using multiple scenarios of landowner values. Specifically, we modeled outcomes for a 30-ha property at 750-m elevation with 22 ha of forest, approximately the mean characteristics of properties owned by the workshop participants as determined from county records and aerial photographs. According to experts at Forest Stewards (a nonprofit corporation affiliated with Western Carolina University that promotes and implements sustainable forest management in the southern Appalachians) who have worked in Macon County, an average, large, private forest in Macon County is about 60 years old, and a timber harvest could be conducted in 10-30 years. We considered a 30-year time frame for our decision analysis because one timber harvest could occur and landownership turnover is likely after 30 years, especially because more than $25 \%$ of the Macon County population is over 65 years of age (U.S. Census Bureau 2013).

\section{Recruiting landowners}

Typically when SDM is used to address public resource management, stakeholders representing the full range of interests related to the decision are invited to participate. Therefore, we sought to include landowners with diverse socio-demographic backgrounds and property characteristics, because these traits were expected to relate to land use values. Further, many scientists who have conducted social-ecological research in Macon County through the Coweeta Long Term Ecological Research (LTER) program hypothesized that multigenerational landowners and new residents have different land use values and practices.

To identify landowners for the SDM workshops, we interviewed 50 owners of large, forested properties (at least 20 ha in total area with at least 4 ha of forest) in Macon County (Institutional Review Board project number 2012108313). Interviewees were identified through a combination of snowball and random stratified sampling (Bernard 2002). Twenty landowners expressed interest in participating in the SDM workshops, and because this was a feasible size for workshops, all were invited. We scheduled 2 series of workshops and assigned 10 landowners to each series such that landowner diversity within a series was maximized (Table 1). The two series were independent because landowner composition remained constant within a series. Each series consisted of four workshops, and all workshops were moderated by P.F. in the 
Table 1. Backgrounds of the landowners who participated in the structured decision-making workshops, as determined from interviews with landowners, land trust records, and county parcel records. We specify when landowners did not grow up in Macon County but had family members who lived there. When landowners owned multiple adjacent parcels, we determined the mean elevation, the sum of the area and value, and whether there was an easement on any part of the property. When landowners owned multiple disjunct parcels, we only considered parcels that were at least 8 ha in area. To keep participant identity confidential, values were rounded to the nearest $10 \mathrm{~m}$ for elevation, 5 ha for area, and $\$ 10,000$ for value.

\begin{tabular}{|c|c|c|c|c|c|c|c|}
\hline Series & $\begin{array}{c}\text { Native to Macon } \\
\text { County }\end{array}$ & Elevation (m) & Total area (ha) & $\begin{array}{c}\text { Contiguous forest } \\
\text { area (ha) }\end{array}$ & Land value (\$) & Building value & Easement \\
\hline 1 & Yes & 670 & 20 & 15 & $1,000,000$ & 340,000 & No \\
\hline 1 & Yes & 760,980 & 35,20 & 35,20 & 850,$000 ; 70,000$ & 40,$000 ; 0$ & No \\
\hline 1 & Yes & 720 & 30 & 25 & $1,00,000$ & 340,000 & No \\
\hline 1 & Family & 680 & 30 & 15 & 750,000 & 250,000 & No \\
\hline 1 & No & 650 & 15 & 15 & 430,000 & 100,000 & Yes \\
\hline 1 & No & 710 & 20 & 20 & 600,000 & 180,000 & No \\
\hline 1 & No & 610 & 25 & 10,5 & 360,000 & 80,000 & Yes \\
\hline 1 & No & 890 & 20 & 20 & 350,000 & 0 & No \\
\hline 2 & Yes & 700 & 65 & 65 & $1,560,000$ & 0 & No \\
\hline 2 & Yes & 650 & 50 & 10 & $1,270,000$ & 120,000 & No \\
\hline 2 & Yes & 650 & 5 & 5 & 190,000 & 270,000 & No \\
\hline 2 & Family & 790 & 30 & 30 & 600,000 & 910,000 & No \\
\hline 2 & No & 690 & 25 & 20 & 600,000 & 280,000 & Yes \\
\hline 2 & No & 700,750 & 20,10 & 15,10 & 680,$000 ; 280,000$ & 210,$000 ; 0$ & No \\
\hline 2 & No & 1160 & 50 & 50 & 328,000 & $1,560,000$ & No \\
\hline
\end{tabular}

conference room at the U.S. Forest Service's Coweeta Hydrologic Laboratory in Otto, North Carolina. Three workshops were held in the summer of 2012, one workshop was held in the summer of 2013, and they lasted about three hours each.

\section{Workshops with landowners}

\section{Workshop 1: objectives}

The goal of the first workshop was for landowners to identify their land use objectives (Keeney 1992). Based on the landowners' comments, we constructed an objectives network, a diagram distinguishing fundamental and means objectives (McDaniels 2000). Fundamental objectives represent the primary values that are inherently important to the decision maker, whereas means objectives highlight the path to achieving fundamental objectives (Keeney 1992, Clemen 1996). We identified some fundamental objectives that were composed of first-order and second-order fundamental objectives. Second-order fundamental objectives describe the components of a first-order fundamental objective that are important to a landowner.

Workshop 2: attributes, decision options, and influence diagram The goals of the second workshop were to identify attributes to make the fundamental objectives measurable, brainstorm decision options, and begin to construct an influence diagram. Attributes provide the scales to measure the degree to which outcomes from a decision satisfy fundamental objectives (Failing et al. 2007, Wilson and McDaniels 2007, Gregory and Long 2009). When there was no natural scale (e.g., hectares) for a fundamental objective, the landowners created a scale with explicitly defined levels through consensus-based discussion (Keeney and Gregory 2005, Miller et al. 2010).

Determining fundamental objectives at the beginning of the decision-making process facilitates identifying creative decision options (McDaniels 2000). Landowners determined decision options through consensus-based discussion (Miller et al. 2010).
The objectives network provided the framework for an influence diagram (Marcot et al. 2001, 2006). An influence diagram consists of nodes, which represent variables, connecting the decision options to fundamental objectives, and arrows, which represent causal links between variables. Each node can take one of multiple discrete states (Marcot et al. 2001). Landowners discussed what nodes should be included and how to connect nodes so that the influence diagram realistically described how forest management decisions affect fundamental objectives. The influence diagram, and later the Bayesian decision network, was built in Netica 4.09 (Norsys Software Corp., Vancouver, British Columbia, Canada).

\section{Workshop 3: objective weights and attribute scores}

The goals of the third workshop were to identify the landowners' objective weights and attribute scores. The influence diagram provides the structure for a Bayesian decision network, a model that predicts expected outcomes for each decision option and assesses how well the expected outcomes satisfy fundamental objectives (Conroy et al. 2008, Miller et al. 2010, Irwin et al. 2011). To analyze the decision options in a Bayesian decision network, objective weights and attribute scores were required. An objective weight reflects the relative importance of the objective to the landowner, with a larger weight indicating greater importance. An attribute score reflects how satisfied a landowner would be if that level in the attribute scale occurred. Landowners completed worksheets to identify their objective weights, using the swing weighting method, and to assign attribute scores (Clemen 1996; Appendices 1 and 2).

\section{Conditional probabilities}

Between the third and fourth workshops, we identified conditional probabilities for the decision network, calculated expected utility values for each decision option, and compared expected utility values to determine a decision recommendation. Conditional probabilities describe the likelihood that each level in a node is realized given states of influencing nodes (Oliver and Smith 1990, Marcot et al. 2001). We searched the scientific 
Fig. 1. Landowners' first-order fundamental objectives (blue), second-order fundamental objectives (purple), and attribute scales (orange). For some objectives, the number of levels in the attribute scale varied between the two stuctured decision-making workshop series, but the maximum number of levels are presented here. Also, the aesthetics objective was included in series 2 only. See Figure 2 for additional details.

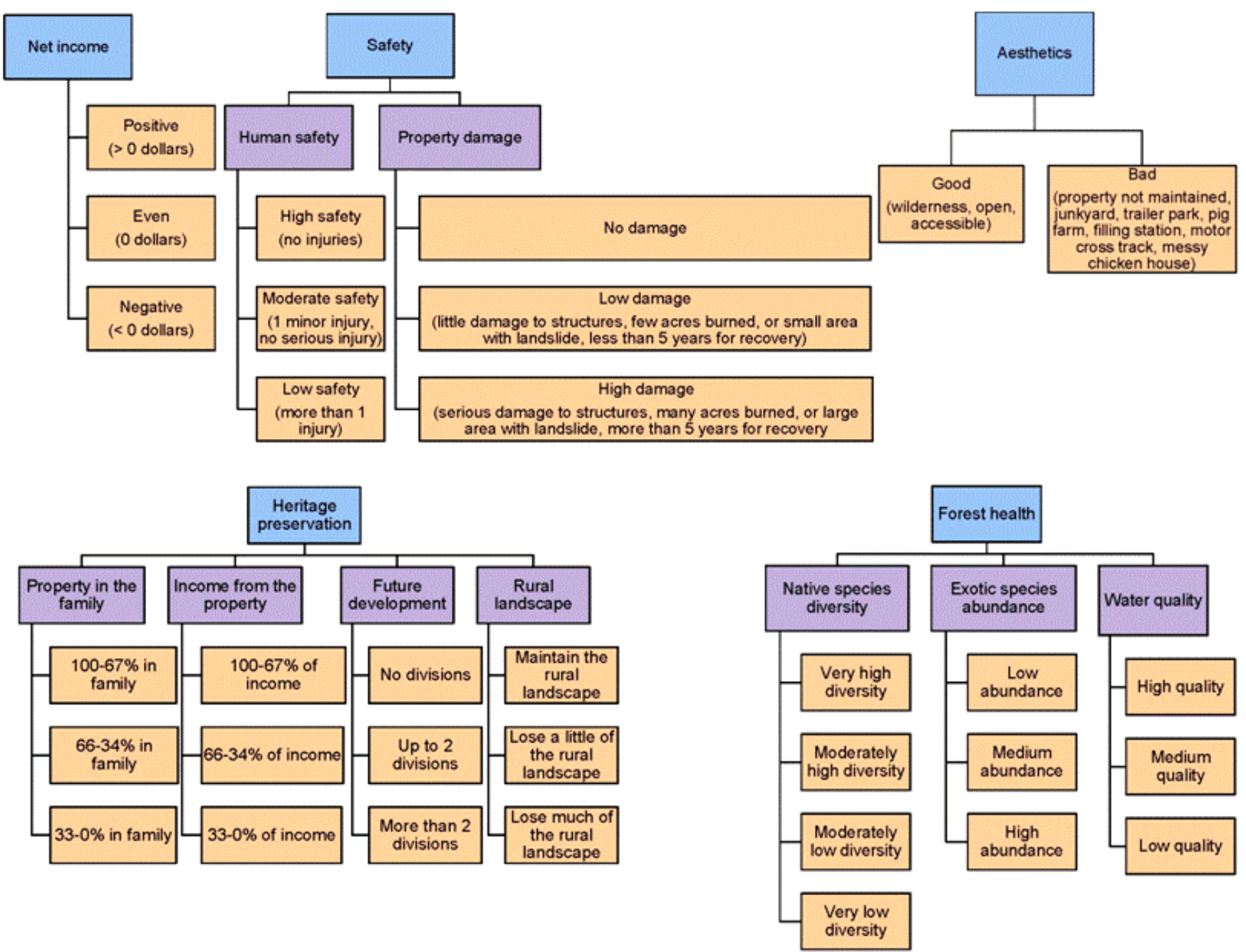

literature for relevant studies from which probabilities of outcomes could be obtained. However, we found that papers rarely presented results in this form. Therefore, we used the available scientific literature to develop hypotheses about system dynamics, but we relied on expert opinion for probabilities (Haas 1991, 2001, Clemen 1996, Peterson and Evans 2003). See Appendix 3 for a discussion of using expert opinion in SDM. We sent worksheets to 33 experts to elicit conditional probabilities. These experts consisted of faculty at the University of Georgia (UGA), faculty at other institutions who are affiliated with Coweeta LTER, graduate students at UGA who had conducted research at Coweeta, U.S. Forest Service employees at the Coweeta Hydrologic Laboratory, a Macon County government employee, staff from the Land Trust for the Little Tenneessee, which is based in Macon County, and staff from Forest Stewards. When we received probabilities for a node from more than one expert, we made a new node for expert identity that affected the nature node. Through the expert identity node, we weighted each expert's probabilities equally, reflecting equal belief in each expert's contribution. Landowners provided conditional probabilities related to heritage, a topic on which they were the best qualified experts, through consensus-based discussion. Through the use of probabilities, we incorporated environmental stochasticity and partial controllability in the predictions of outcomes following decisions (Williams et al. 1996, Conroy et al. 2008, Irwin et al. 2011).

\section{Utility values}

Utility functions combine the probability of outcomes and landowners' satisfaction with outcomes such that the expected utility value indicates the relative suitability of the decision option. Expected utility values were calculated for each decision by a weighted average of the objective weights, attribute scores, and conditional probabilities (Peterson and Evans 2003). All combinations of objective weights and attribute scores, generating scenarios of landowner values, were used to calculate 
expected utility values. The sets of optimal and least-desirable decision options were defined as decision options with utility values within one point of the highest or lowest utility value, respectively. The frequency with which each decision option fell in the set of optimal or least-desirable decision options was recorded.

$$
U=\sum_{D=1}^{F} W_{D}\left(\sum_{s=1}^{G} U_{s}\left(\sum_{v=1}^{H} S_{v} \times \operatorname{Pr}\left(X_{v} \mid A\right)\right)\right)
$$

We calculated the expected utility according to equation (1) where $W$ indicates a first-order fundamental objective weight, $U$ indicates a second-order fundamental objective weight, and $S$ represents an attribute score. For each of the $G$ second-order fundamental objectives $(s=1,2, \ldots, G)$ within a first-order fundamental objective $(p=1,2, \ldots, F)$, we weighted the attribute score for a possible outcome $(v=1,2, \ldots, H)$ by the probability of that outcome $\left(X_{v}\right)$ given states of influencing nodes $(A)$. Note that $G$ may depend on $p$ and $H$ may depend on $p$ and $s$.

Workshop 4: landowners' assessment

At the fourth workshop, we presented the completed decision network and discussed the optimal and least-desirable decision options. We also asked landowners to complete questionnaires addressing their experience with the SDM project (Appendix 4). One questionnaire was distributed before we presented results and one was distributed after.

\section{RESULTS}

\section{Decision network inputs}

A small set of fundamental objectives were identified by the landowners: maximizing forest health, safety, heritage preservation, and net income, but the landowners in series 2 included maximizing aesthetic enjoyment. For some of these fundamental objectives, landowners also defined second-order fundamental objectives, which described components of a firstorder fundamental objective while remaining fundamental objectives themselves (Fig. 1).

Because objective weights and attribute scores are based on values, we did not consider responses from landowners right or wrong, but they had to be logically consistent; outcomes that were considered better needed a higher attribute score. We found many inconsistencies in the worksheets used to elicit objective weights and attribute scores, so we eliminated those responses and collated all of the logically consistent responses across all landowners. If a landowner completed all components of the worksheet correctly, their responses were used to calculate a set of objective weights or attribute scores (Appendices 5-6). The consistent responses from landowners who did not complete the entire worksheet correctly were used to calculate a set of mean objective weights or mean attribute scores. Therefore, for series 1 there were 4 scenarios of objective weights and attribute scores, and for series 2 there were 24 scenarios. The expected utilities of the decision options were compared under each scenario.

The landowners identified 11 decision options: no modification of the forest, personal use of the forest (e.g., collecting firewood, building and using recreational trails), crown-thinning harvest through the Present-Use Value (PUV) program, group selection harvest through the PUV program, shelterwood harvest with residual trees through the PUV program, each of the above with a conservation easement, and sell 1 ha (approximately $5 \%$ of the forest) with personal use of the remaining forest (Figs. 2 and 3). Details about conservation easements and the PUV program can be found in Appendix 7.

Eight experts provided conditional probabilities (Appendix 8). On average, two experts contributed conditional probabilities for each node other than those for heritage or aesthetic objectives, for which landowners provided probabilities. See Appendices 9 and 10 for more details about the decision network.

\section{Optimal decision option}

The decision option with the largest or smallest utility value varied depending on the scenario of landowner values (Appendix 11). The decision most often included in the set of optimal decision options was crown thinning in the PUV program, and the consistently least-desirable decisions were selling 1 ha and personal use of the forest with or without a conservation easement (Table 2).

Table 2. Optimal and least-desirable decision options from two structured decision-making workshop series. Utility values, which indicate the relative suitability of decision options, were calculated using all combinations of objective-weight and attribute-score scenarios. The number of times a decision option was within one point of the highest utility value or within one point of the lowest utility value are presented as the frequency of being the optimal or least-desirable decision. Personal use of the forest could involve harvesting firewood or using recreational trails. The three commercial harvesting methods (thinning, group selection, and shelterwood) would occur through the Present-Use Value program. The no modification, personal use, and commercial harvesting decision options could also be combined with having a conservation easement (Appendix 7).

\begin{tabular}{|c|c|c|c|c|}
\hline \multirow[b]{2}{*}{ Decision options } & \multicolumn{2}{|c|}{$\begin{array}{l}\text { Series } 1 \text { ( } 4 \text { value } \\
\text { scenarios) }\end{array}$} & \multicolumn{2}{|c|}{$\begin{array}{c}\text { Series } 2 \text { ( } 24 \text { value } \\
\text { scenarios) }\end{array}$} \\
\hline & $\begin{array}{l}\text { Optimal } \\
\text { decision } \\
\text { frequency }\end{array}$ & $\begin{array}{c}\text { Least- } \\
\text { desirable } \\
\text { decision } \\
\text { frequency }\end{array}$ & $\begin{array}{l}\text { Optimal } \\
\text { decision } \\
\text { frequency }\end{array}$ & $\begin{array}{c}\text { Least- } \\
\text { desirable } \\
\text { decision } \\
\text { frequency }\end{array}$ \\
\hline No modification & 0 & 0 & 8 & 0 \\
\hline Personal use & 0 & 3 & 0 & 11 \\
\hline Thinning & 4 & 0 & 23 & 0 \\
\hline Group selection & 0 & 0 & 0 & 0 \\
\hline Shelterwood & 3 & 0 & 5 & 1 \\
\hline $\begin{array}{l}\text { Easement with no } \\
\text { modification }\end{array}$ & 0 & 0 & 7 & 0 \\
\hline $\begin{array}{l}\text { Easement with personal } \\
\text { use }\end{array}$ & 0 & 3 & 0 & 11 \\
\hline Easement with thinning & 0 & 0 & 0 & 0 \\
\hline $\begin{array}{l}\text { Easement with group } \\
\text { selection }\end{array}$ & 0 & 0 & 0 & 1 \\
\hline $\begin{array}{l}\text { Easement with } \\
\text { shelterwood }\end{array}$ & 1 & 0 & 0 & 1 \\
\hline $\begin{array}{l}\text { Sell } 1 \text { ha, remainder } \\
\text { personal use }\end{array}$ & 0 & 1 & 1 & 13 \\
\hline
\end{tabular}


Fig. 2. Bayesian decision networks based on landowners' comments during structured decision-making workshop series 1 . The decision network calculates utility values (shown in the blue rectangle) through the utility node (pink hexagon) for each decision option. The decision option with the greatest expected utility is the most likely to achieve the landowners' objectives. Stochastic (green rectangles) and deterministic (brown rectangle) nature nodes link the decision options to the utility node. Arrows indicate dependencies such that the probabilities of levels in a node occurring are conditional on the states in antecedent nodes. The numbers next to the bars in a nature node depict the percent probability of that level occurring. Utility values from the mean objective-weight and attribute-score scenarios are shown for both series (Appendices 5 and 6). PUV indicates Present-Use Value.

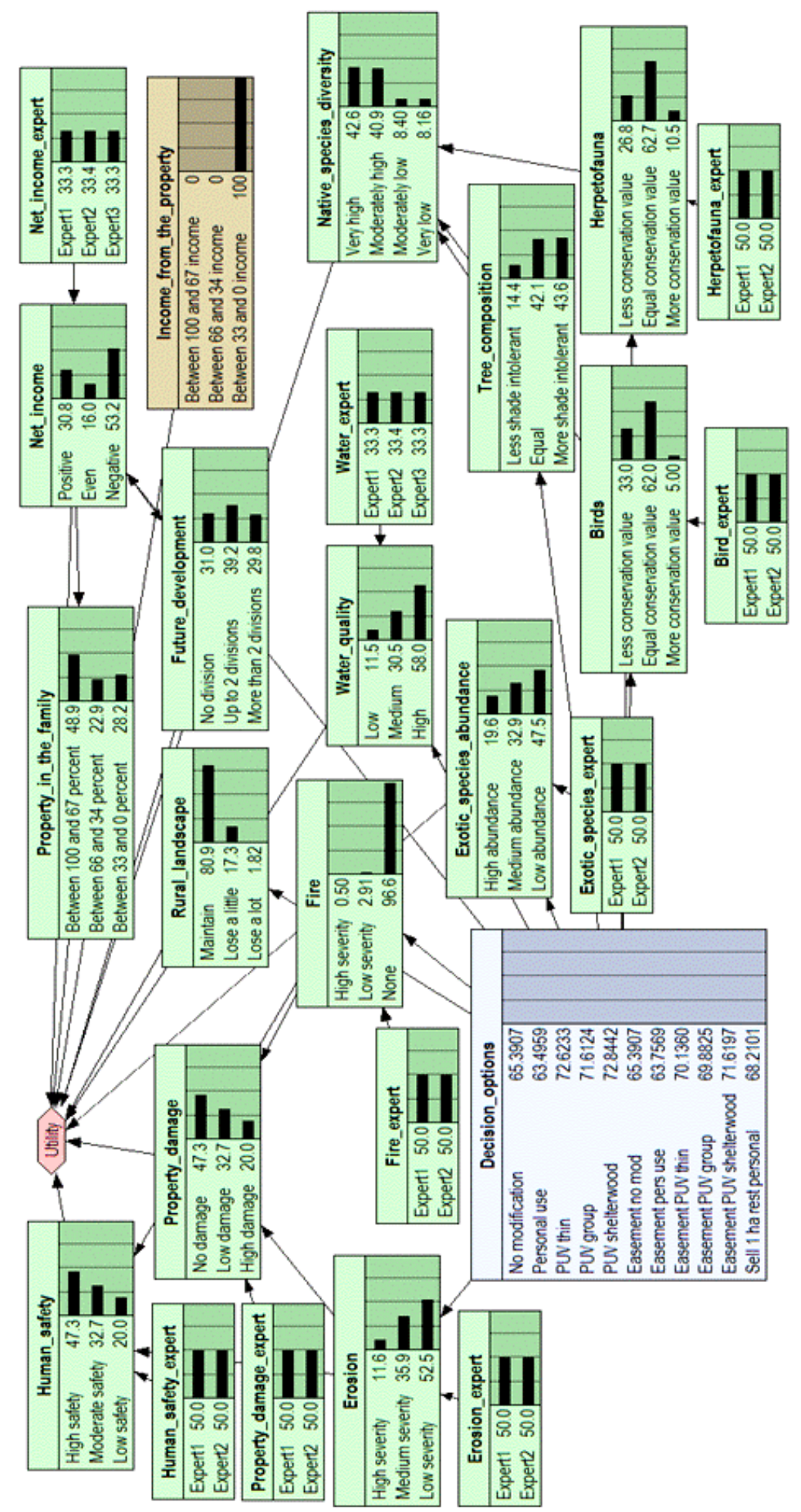


Fig. 3. Bayesian decision networks based on landowners' comments during structured decision-making workshop series 2. The decision network calculates utility values (shown in the blue rectangle) through the utility node (pink hexagon) for each decision option. The decision option with the greatest expected utility is the most likely to achieve the landowners' objectives. Stochastic (green rectangles) and deterministic (brown rectangle) nature nodes link the decision options to the utility node. Arrows indicate dependencies such that the probabilities of levels in a node occurring are conditional on the states in antecedent nodes. The numbers next to the bars in a nature node depict the percent probability of that level occurring. Utility values from the mean objective-weight and attribute-score scenarios are shown for both series (Appendices 5 and 6). PUV indicates Present-Use Value.

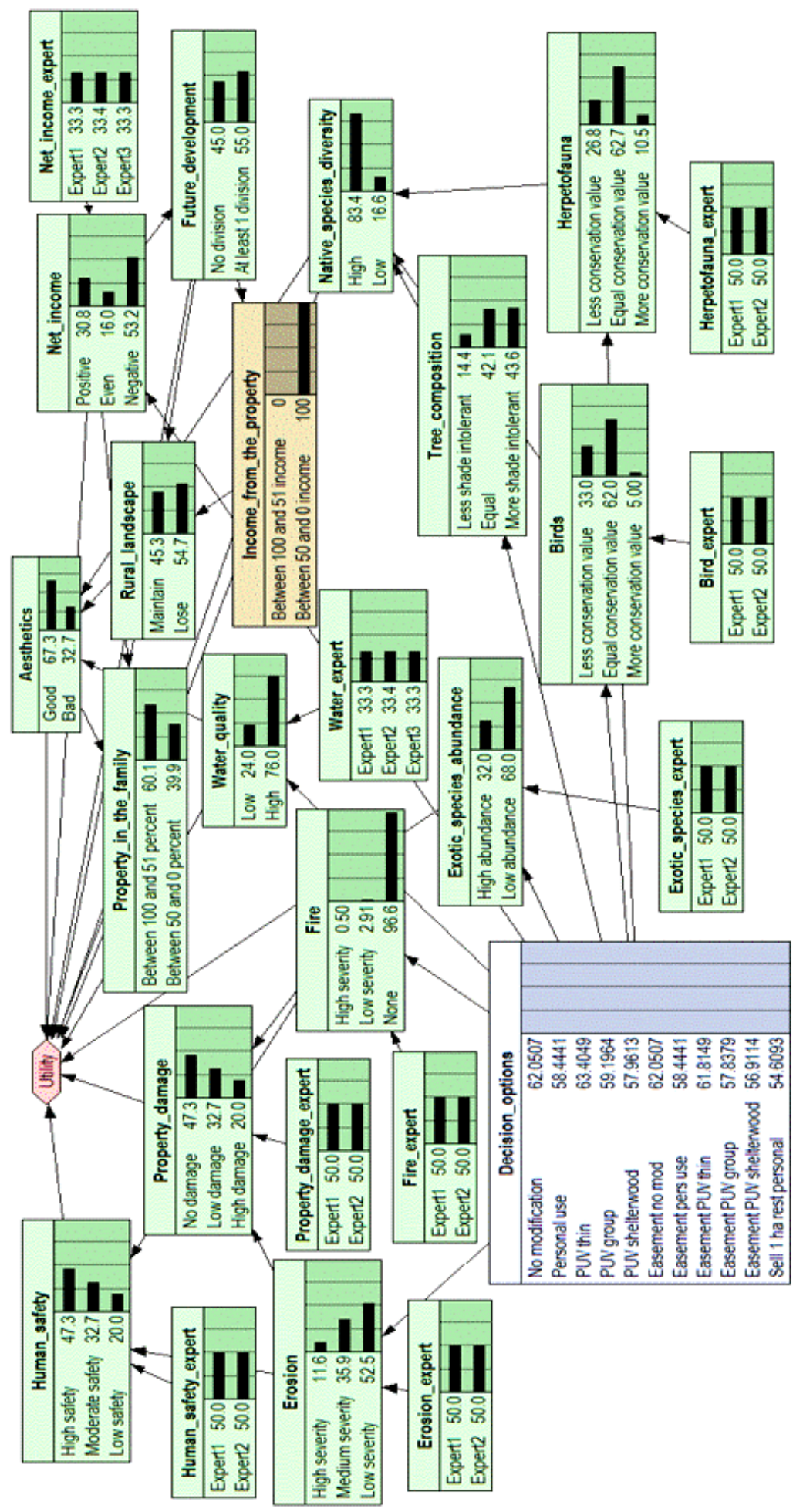


Table 3. Landowners' thoughts and behaviors related to decision options from the structured decision-making project, as determined from questionnaires completed before and after results of the decision network. Presented are the proportion of landowners (out of 13 who completed questionnaires) who, before results were presented, expected that a given decision option would be indicated by the decision network as optimal; who currently use a given decision option; and who indicated they would investigate a given decision option after seeing results. The proportion of landowner value scenarios (out of 28) in which each decision option was indicated by the decision network as optimal or least desirable is also shown.

\begin{tabular}{|c|c|c|c|c|c|}
\hline Decision option & Expected optimal & Current use & Will investigate & Optimal & $\begin{array}{c}\text { Least- } \\
\text { desirable }\end{array}$ \\
\hline No modification & 0.13 & 0.22 & 0 & 0.15 & 0 \\
\hline Personal use & 0.40 & 0.22 & 0.13 & 0 & 0.31 \\
\hline Thinning & 0.20 & 0.28 & 0.38 & 0.52 & 0 \\
\hline Group selection & 0 & 0.11 & 0.13 & 0 & 0 \\
\hline Shelterwood & 0 & 0.11 & 0 & 0.15 & 0.02 \\
\hline Easement with no modification & 0 & 0.06 & 0.13 & 0.13 & 0 \\
\hline Easement with personal use & 0.13 & 0 & 0.13 & 0 & 0.31 \\
\hline Easement with thinning & 0.13 & 0 & 0.13 & 0 & 0 \\
\hline Easement with group selection & 0 & 0 & 0 & 0 & 0.02 \\
\hline Easement with shelterwood & 0 & 0 & 0 & 0.02 & 0.02 \\
\hline Sell 1 ha, remainder personal use & 0 & 0 & 0 & 0.02 & 0.31 \\
\hline
\end{tabular}

Under some landowner value scenarios, the optimal decisions were no modification of the forest with or without a conservation easement, shelterwood harvest in the PUV program with a conservation easement, and selling 1 ha. In certain landowner value scenarios, the least-desirable decisions were shelterwood harvest in the PUV program with or without a conservation easement and group selection harvest in the PUV program with a conservation easement.

\section{Landowners' assessments}

The forest management practices that the decision network indicated were optimal were often different from those anticipated by the landowners. Only $33 \%$ of landowners correctly identified an optimal decision option, and 53\% expected decision options to be optimal when the decision network actually identified them as the least-desirable decision option (Table 3). However, many landowners $(67 \%)$ currently use the optimal practices according to the decision network (Table 3). Many landowners said they would consider management options other than those they currently use, and the SDM project influenced this opinion. After discussing the decision network results, the number of landowners who indicated that, in general, they would reconsider what they are currently doing to manage their forest increased by $46 \%$. (Tables 3 and 4).

Eighty-five percent of landowners had a good experience participating in the project, and 69\% said they understood most of the material presented during the project. All understood at least half of the material. Some aspects of the project that landowners found beneficial included "meeting others with similar interests in forest conservation," "group discussions of individual management practices and what things participants value," "objectively evaluating our property and values," "watching the decision network grow," and "encouragement to do something beneficial."

\section{DISCUSSION}

\section{Objectives}

A landowner's efforts to avoid parcelization can be supported by a decision tool that includes the diverse factors contributing to a landowner's decision to manage or subdivide a large, private forest (Best 2002). The importance of net income, heritage preservation, and aesthetics to landowners has been prominent in the literature and was discussed by Macon County landowners (Birch 1997, DeCoster 1998, Mehmood and Zhang 2001, Best 2002, Rickenback and Gobster 2003, Kendra and Hull 2005).

Each Macon County landowner held diverse objectives, and there was little variability in objectives among landowners. As opposed to the working hypothesis of many scientists at Coweeta LTER, multigenerational landowners and new residents did not appear to have different objectives. This unexpected pattern was also found by other researchers concurrently conducting socialecological research in Macon County (S. Evans, personal communication).

Our findings are consistent with the notion behind SDM that stakeholders often do not have drastically different objectives; rather, they may assign objective weights and attribute scores differently (Keeney et al. 1990, Gregory and Keeney 1994). Conflict can arise in the decision-making process when this distinction is not recognized and stakeholders feel as if they have to defend their objectives. Instead, building models that incorporate multiple objective-weight and attribute-score scenarios can abate conflicts and facilitate decision making.

\section{Decision network}

Our decision network produced reasonable results. It makes sense that crown thinning in the PUV program would be the optimal decision option because it causes a relatively low level of disturbance, landowners receive income from timber harvesting, and property taxes are reduced. Selling 1 ha and personal use of the forest with or without a conservation easement were the leastdesirable decisions because although personal use of the forest 
Table 4. Landowners' assessment of the structured decision-making (SDM) project, as determined from questionnaires completed before and after results of the decision network. The proportion of landowners (out of 13 who completed questionnaires) whose behavior might be affected by SDM results and landowners' experiences of the SDM project are indicated.

\begin{tabular}{|c|c|c|c|c|}
\hline & Relative to seeing results & Yes & Maybe & No \\
\hline Reevaluate preference for decisions & Before & 0.85 & 0.08 & 0.08 \\
\hline Results affect how you manage & Before & 0.23 & 0.54 & 0.23 \\
\hline Consider stopping current management & Before & 0.08 & 0.54 & 0.38 \\
\hline Consider starting new management & Before & 0.54 & 0.46 & 0.00 \\
\hline Want SDM personalized & After & 0.15 & 0.38 & 0.46 \\
\hline Would pay for SDM & After & 0.31 & 0.00 & 0.69 \\
\hline Reconsider how you manage & After & 0.69 & 0.15 & 0.15 \\
\hline Investigate new management & After & 0.15 & 0.54 & 0.31 \\
\hline
\end{tabular}

causes a relatively low level of disturbance, there is no financial return. The property would be taxed at full market value, and establishing a conservation easement is expensive to the landowner. Although there may be financial benefits from selling property, it is detrimental to ecological and heritage objectives.

The robustness of results from the decision network influences how results should be interpreted and applied. In our project, landowners' objective weights and attribute scores influenced which decision was optimal; and in some landowner value scenarios, there was little difference among the utility values for the various decision options. We did not find a single best management practice for large, private forests. When decision options have similar utility values, an optimal decision is less apparent, and it suggests that utility values may not be robust to objective weights, attribute scores, or probabilities. This emphasizes the need to tailor the decision network to an individual landowner and their property.

Use of expert opinion is an established practice in SDM applications when a decision must be made given the current best technical information, however incomplete (Appendix 3). We found that the conditional probabilities we obtained from experts were consistent with patterns indicated in the literature (Appendix 12). The effects of conditional probabilities on utility values can be investigated by varying the weights assigned to experts' opinions. Because in our decision network there are 34,992 combinations $(37 * 42$ because there are 7 expert nodes with 3 possible combinations of weights and 2 expert nodes with 4 possible combinations of weights) in which weights might be uniform across the experts in a node or $100 \%$ on one expert in a node, we focused on the decision network from series 1 and landowner value scenario 1 , and did not do an exhaustive analysis. When we varied the weights on experts' opinions, the order of the top few decision options changed. This has implications for a goal of identifying the single decision with the greatest utility value, but decision networks do not need to be considered authoritative. They are meant to be decision support tools, so decision makers could identify the few decision options that most consistently have high utility values and engage in additional decision-making strategies to arrive at a final decision.

\section{SDM potency and challenges}

Because SDM can effectively integrate diverse objectives and multiple scientific models, and in the process reduce unproductive conflict, it has potential application to broad land use questions in Macon County and elsewhere. For a population that has been resistant to land use regulation, it is notable that $85 \%$ of the landowners had a good experience during the SDM project and $54 \%$ indicated that they might want a decision network made for their property. These results highlight a potential way to improve natural resource management, even in areas where past regulatory attempts have been unproductive.

For this project, our goal was to evaluate the potential utility of SDM to assist a landowner with a decision about their natural resources when the community has been resistant to regulation. Therefore, we held workshops including diverse landowners and analyzed a hypothetical property. This procedure allowed us to test SDM with a variety of landowners and minimize the appearance of being prescriptive about someone's property. In actual application, an individual landowner's objectives, decision options, and weights would be used in the decision network.

Besides individual landowners, conservation and land use planning organizations can benefit from using SDM to guide decisions about their operations or to support clients' decision making. In some of these cases, it may be appropriate for a group of stakeholders to participate in a SDM process. A group SDM process is suitable when there are multiple stakeholders, such as conservation organization members, that share a common resource, such as the conservation organization's operating procedures (Peterson and Evans 2003, Miller et al. 2010).

SDM also could be a way to make inroads into county-level land use or residential development decision making. There may be greater success in decision making when the process involves stakeholders throughout, explicitly incorporates diverse stakeholder values, addresses uncertainty, and is transparent. If county land use questions can be addressed in a SDM process that allows landowners to feel represented and respected, effectively integrates value-based and technical information, and avoids political tension, future decision making may be more successful than past attempts.

Some benefits of SDM that apply to both group and individual applications include (1) after systematic analysis realizing the optimal decision is different than the initially favored decision option and (2) identifying and reducing uncertainty in decision making. The first benefit was seen in this project: Landowners $(40 \%)$ initially expected personal use to be the optimal decision, but the SDM analysis indicated that crown thinning in the PUV program was actually the optimal decision. The second benefit 
occurs because not all uncertainties have an equal effect on decision making. The most influential model components can be identified, and additional data can be collected to reduce uncertainty in key model components. Finally, SDM fits well with adaptive resource management. After a decision is made, the system is monitored, decision outcomes are compared with predicted outcomes from multiple models, uncertainty about system dynamics is reduced, and subsequent decisions incorporate this new information (Conroy and Peterson 2013).

However, there are challenges associated with SDM. There may be linguistic uncertainty and miscommunication. In our project, $69 \%$ of landowners said they understood most of the material. Nevertheless, there were many inconsistencies in the objective weights and attribute scores reported on the worksheets. We recommend that researchers assess each participant's understanding and contributed information immediately and throughout the project, but this may be difficult given the researcher-to-participant ratio or time constraints. Additionally, obtaining conditional probabilities for the decision network can be challenging, given how results are often presented in the scientific literature and possibly limited transferability of results from previous studies to the SDM decision context. If expert opinion is the most suitable source of conditional probabilities, communication with consulted experts also may be challenging. Scientists often have not been trained in the distinction between and proper roles of value-based information and technical information (Failing et al. 2007).

\section{CONCLUSION}

Owners of large, private forests often have multiple ecological, economic, and social objectives motivating their land use decision making. A decision-making process, such as SDM, that helps landowners identify creative decision options and evaluate them in light of their objectives and uncertainty can help prevent parcelization and forest fragmentation. By participating in SDM, decision makers may benefit by reflecting on their values, learning technical information, and identifying decision options that are most likely to meet their objectives. Because SDM is participatory, transparently incorporates value-based and technical information, and includes uncertainty, it is an effective way to rigorously evaluate options for decision problems that are controversial or that have incomplete data. Our SDM project with owners of large, forested parcels in Macon County, North Carolina, found that crown thinning in the PUV program was the optimal forest management decision, and selling 1 ha of forest or personal use of the forest with or without a conservation easement were the least-desirable decisions for an average, large, forested property in Macon County. We have demonstrated that SDM can be effective in many challenging decision contexts.

\section{Responses to this article can be read online at:}

http://www.ecologyandsociety.org/issues/responses. $\mathrm{php} / 7996$

\section{Acknowledgments:}

We thank all of the Macon County landowners who participated in this project and colleagues who helped us meet landowners, including
B. McRae, B. McLarney, C. Smalling, D. Shure, G. Wein, J. Love, J. Meador, J. Hunnicutt, K. McLean, P. Moore, R. Regnery, S. Guffey, and $W$. Swank. We appreciate feedback on this project from R. Cooper, J. Maerz, S. Evans, T. Gragson, N. Heynen, and the Coweeta Listening Project. Expert information was provided by $D$. Green, D. Desmond, J. Hatt, J. Frisch, K. Servidio, K. Cecala, M. Cline, R. Lamb, and T. Allen. Funding was provided by the Coweeta Long Term Ecological Research Project (NSF grant DEB-0823293), the USDA CSREES McIntire-Stennis Project (GEOZ-0159-MS), the Georgia Ornithological Society, the Warnell School of Forestry and Natural Resources at the University of Georgia, the University of Georgia Graduate School, and the Georgia Museum of Natural History.

\section{LITERATURE CITED}

Barnes, B. V. 1991. Deciduous forests of North America. Pages 219-344 in E. Röhrig and B. Ulrich, editors. Ecosystems of the world. Temperate deciduous forests. Volume 7. Elsevier, New York, New York, USA.

Bernard, H. R. 2002. Research methods in anthropology: qualitative and quantitative methods. AltaMira, Walnut Creek, California, USA.

Best, C. 2002. America's private forests: challenges for conservation. Journal of Forestry 100(3):14-17.

Birch, T. W. 1997. Private forest-land owners of the southern United States, 1994. Resource Bulletin NE-138. U.S. Department of Agriculture Forest Service, Northeastern Forest Experiment Station, Washington, D.C., USA.

Cho, S.-H., S. G. Kim, R. K. Roberts, and S. Jung. 2009. Amenity values of spatial configurations of forest landscapes over space and time in the southern Appalacian Highlands. Ecological Economics 68:2646-2657. http://dx.doi.org/10.1016/j.ecolecon.2009.04.017

Clemen, R. T. 1996. Making hard decisions: an introduction to decision analysis. Duxbury, Pacific Grove, California, USA.

Conroy, M. J., and J. T. Peterson. 2013. Decision making in natural resource management: a structured, adaptive approach. WileyBlackwell, Hoboken, New Jersey, USA. http://dx.doi. org/10.1002/9781118506196

Conroy, M. J., R. J. Barker, P. W. Dillingham, D. Fletcher, A. M. Gormley, and I. M. Westbrooke. 2008. Application of decision theory to conservation management: recovery of Hector's dolphin. Wildlife Research 35:93-102. http://dx.doi.org/10.1071/ $\underline{\text { WR07147 }}$

Cumming, G., and C. Norwood. 2012. The community voice method: using participatory research and filmmaking to foster dialog about changing landscapes. Landscape and Urban Planning 105:434-444. http://dx.doi.org/10.1016/j.landurbplan.2012.01.018

DeCoster, L. A. 1998. The boom in forest owners - a bust for forestry? Journal of Forestry 96(5):25-28.

Egan, A. F., and A. E. Luloff. 2000. The exurbanization of America's forests:research in rural social science. Journal of Forestry 98(3):26-30.

Failing, L., R. Gregory, and M. Harstone. 2007. Integrating science and local knowledge in environmental risk management: 
a decision-focused approach. Ecological Economics 64:47-60. http://dx.doi.org/10.1016/j.ecolecon.2007.03.010

Gobster, P. H., and M. G. Rickenbach. 2004. Private forest parcelization and development in Wisconsin's Northwoods: perceptions of resource-oriented stakeholders. Landscape and Urban Planning 69:165-182. http://dx.doi.org/10.1016/j. landurbplan.2003.09.005

Gragson, T. L., and P. V. Bolstad. 2006. Land use legacies and the future of southern Appalachia. Society \& Natural Resources 19:175-190. http://dx.doi.org/10.1080/08941920500394857

Gregory, R., L. Failing, M. Harsotne, G. Long, T. McDaniels, and D. Ohlson. 2012. Structured decision making: a practical guide to environmental management choices. Wiley-Blackwell, Hoboken, New Jersey, USA. http://dx.doi.org/10.1002/97814443398557

Gregory, R., and R. L. Keeney. 1994. Creating policy alternatives using stakeholder values. Management Science 40(8):1035-1048. http://dx.doi.org/10.1287/mnsc.40.8.1035

Gregory, R., and G. Long. 2009. Using structured decision making to help implement a precautionary approach to endangered species management. Risk Analysis 29(4):518-532. http://dx.doi.org/10.1111/j.1539-6924.2008.01182.x

Gregory, R. S., and R. L. Keeney. 2002. Making smarter environmental management decisions. Journal of the American Water Resources Association 38(6):1601-1612. http://dx.doi. org/10.1111/j.1752-1688.2002.tb04367.x

Groom, M., D. B. Jensen, R. L. Knight, S. Gatewood, L. Mills, D. Boyd-Heger, L. S. Mills, and M. E. Soule. 1999. Buffer zones: benefits and dangers of compatible stewardship. Pages 171-197 in M. E. Soule and J. Terborgh, editors. Continental conservation: scientific foundations of regional reserve networks. Island Press, Washington, D.C., USA.

Haas, T. C. 1991. A Bayesian belief network advisory system for aspen regeneration. Forest Science 37:627-654.

Haas, T. C. 2001. A web-based system for public-private sector collaborative ecosystem management. Stochastic Environmental Research and Risk Assessment 15:101-131. http://dx.doi. org/10.1007/s004770000062

Harper, S. C., L. L. Falk, and E. W. Rankin. 1990. The northern forest lands study of New England and New York. U.S. Department of Agriculture Forest Service, Rutland, Vermont, USA.

Irwin, B. J., M. J. Wilberg, M. L. Jones, and J. R. Bence. 2011. Applying structured decision making to recreational fisheries management. Fisheries 36(3):113-122. http://dx.doi.

org/10.1080/03632415.2011.10389083

Keeney, R. L. 1992. Value-focused thinking: a path to creative decision making. Harvard University Press, Cambridge, Massachusetts, USA.

Keeney, R. L., and R. S. Gregory. 2005. Selecting attributes to measure the achievement of objectives. Operations Research 53 (1):1-11. http://dx.doi.org/10.1287/opre.1040.0158

Keeney, R. L., D. van Winterfeldt, and T. Eppel. 1990. Eliciting public values for complex policy decisions. Management Science 36(9):1011-1030. http://dx.doi.org/10.1287/mnsc.36.9.1011
Kendra, A., and R. B. Hull. 2005. Motivations and behaviors of new forest owners in Virginia. Forest Science 51(2):142-154.

Ko, D. W., and H. S. He. 2011. Characterizing the historical process of private forestland ownership parcelization and aggregation in the Missouri Ozarks, USA, from 1930 to 2000. Landscape and Urban Planning 102:262-270. http://dx.doi. org/10.1016/j.landurbplan.2011.05.004

Lando, T. 2003. The public hearing process: a tool for citizen participation, or a path toward citizen alienation? National Civic Review 92(1):73-82. http://dx.doi.org/10.1002/ncr.7

Marcot, B. G., R. S. Holthausen, M. G. Raphael, M. M. Rowland, and M. J. Wisdom. 2001. Using Bayesian belief networks to evaluate fish and wildlife population viability under land management alternatives from an environmental impact statement. Forest Ecology and Management 153:29-42. http://dx. doi.org/10.1016/S0378-1127(01)00452-2

Marcot, B. G., J. D. Steventon, G. D. Sutherland, and R. K. McCann. 2006. Guidelines for developing and updating Bayesian belief networks applied to ecological modeling and conservation. Canadian Journal of Forest Research 36:3063-3074. http://dx.doi. org/10.1139/x06-135

McDaniels, T. L. 2000. Creating and using objectives for ecological risk assessment and management. Environmental Science \& Policy 3:299-304. http://dx.doi.org/10.1016/s1462-9011 (00)00108-8

Mehmood, S. R., and D. Zhang. 2001. Forest parcelization in the United States:a study of contributing factors. Journal of Forestry 99(4):30-34.

Miller, T. J., J. A. Blair, T. F. Ihde, R. M. Jones, D. H. Secor, and M. J. Wilberg. 2010. FishSmart: an innovative role for science in stakeholder-centered approaches to fisheries management. Fisheries 35(9):424-433. http://dx.doi.org/10.1577/1548-8446-35.9.422

Oliver, R. M., and J. Q. Smith. 1990.Influence diagrams, belief nets and decision analysis. John Wiley \& Sons, New York, New York, USA.

Peterson, J. T., and J. W. Evans. 2003. Quantitative decision analysis for sports fisheries management. Fisheries 28(1):10-21. http://dx.doi.org/10.1577/1548-8446(2003)28[10:qdafsf]2.0.co:2

Pollard, K. M. 2005. Population growth and distribution in Appalachia: new realities. Demographic and Socioeconomic Change in Appalachia. Population Reference Bureau, Washington, D.C., USA.

Raymond, C. M., I. Fazey, M. S. Reed, L. C. Stringer, G. M. Robinson, and A. C. Evely. 2010. Integrating local and scientific knowledge for environmental management. Journal of Environmental Management 91:1766-1777. http://dx.doi.org/10.1016/ j.jenvman.2010.03.023

Rickenback, M. G., and P. H. Gobster. 2003. Stakeholders' perceptions of parcelization in Wisconsin's Northwoods. Journal of Forestry 101(8):18-23.

Sampson, N., and L. DeCoster. 2000. Forest fragmentation: implications for sustainable private forests. Journal of Forestry 98 (3):4-8. 
Smith, M. D., and R. S. Krannich. 2000. "Culture clash” revisited: newcomer and longer-term residents' attitudes towards land use, development, and environmental issues in rural communities in the Rocky Mountain West. Rural Sociology 65(3):396-421. http:// dx.doi.org/10.1111/j.1549-0831.2000.tb00036.x

Stewart, W. P., D. Liebert, and K. W. Larkin. 2004. Community identities as visions for landscape change. Landscape and Urban Planning 69:315-334. http://dx.doi.org/10.1016/j.landurbplan.2003.07.005

U.S. Census Bureau. 2013. QuickFacts: Macon County, NC. U. S. Census Bureau, Washington, D.C., USA. [online] URL: http:// www.census.gov/quickfacts/table/PST045214/37113,13193,00

Wear, D. N., R. Liu, J. Foreman, and R. M. Sheffield. 1999. The effects of population growth on timber management and inventories in Virginia. Forest Ecology and Management 118:107-115. http://dx.doi.org/10.1016/S0378-1127(98)00491-5

Williams, B. K., F. A. Johnson, and K. Wilkins. 1996. Uncertainty and the adaptive management of waterfowl harvests. Journal of Wildlife Management 60(2):223-232. http://dx.doi.org/10.2307/3802220

Wilson, C., and T. McDaniels. 2007. Structured decision-making to link climate change and sustainable development. Climate Policy 7:353-370. http://dx.doi.org/10.1080/14693062.2007.9685661 


\section{Appendix 1}

Worksheet to elicit objective weights. Twenty owners of large, forested properties (at least 20 ha in total area with at least 4 ha of forest) in Macon County, North Carolina, participated in a structured decision making (SDM) process consisting of two series of workshops with ten landowners each. In each series, landowners evaluated what they can do to their forest to maximize the achievement of their land use objectives. After landowners identified their objectives, they assigned weights to their objectives. Larger weights indicated greater importance. The landowners in an SDM series shared common objectives, but each landowner assigned their own weights to the objectives. The weights were elicited using this worksheet.

\section{Instructions:}

- Rank scenarios from $1=$ best to last $=$ worst

- Give each scenario a grade between 100 and 0

- The grade reflects how satisfied you would be with that outcome, where $100=$ completely satisfied

- Make sure your grades reflect your ranking

- Scenario ranked 1 has highest grade,

- Scenario ranked 2 has second highest grade, ...

\begin{tabular}{|c|c|c|c|c|c|}
\hline & Native species diversity & Exotic species abundance & Water quality & Rank & Grade \\
\hline Worst & $\begin{array}{l}\text { Large decrease in } \\
\text { native species diversity }\end{array}$ & $\begin{array}{l}\text { Large increase in } \\
\text { exotic species abundance }\end{array}$ & $\begin{array}{l}\text { Large decrease in } \\
\text { water quality }\end{array}$ & 4 & 0 \\
\hline Water scenario & $\begin{array}{l}\text { Large decrease in } \\
\text { native species diversity }\end{array}$ & $\begin{array}{l}\text { Large increase in } \\
\text { exotic species abundance }\end{array}$ & $\begin{array}{l}\text { Large increase in } \\
\text { water quality }\end{array}$ & & \\
\hline Native scenario & $\begin{array}{l}\text { Large increase in } \\
\text { native species diversity }\end{array}$ & $\begin{array}{l}\text { Large increase in } \\
\text { exotic species abundance }\end{array}$ & $\begin{array}{l}\text { Large decrease in } \\
\text { water quality }\end{array}$ & & \\
\hline Exotic scenario & $\begin{array}{l}\text { Large decrease in } \\
\text { native species diversity }\end{array}$ & $\begin{array}{c}\text { Large decrease in } \\
\text { exotic species abundance }\end{array}$ & $\begin{array}{l}\text { Large decrease in } \\
\text { water quality }\end{array}$ & & \\
\hline
\end{tabular}




\begin{tabular}{|c|c|c|c|c|c|c|c|c|}
\hline & Human safety & & roperty safety & Rank & Grade & & & \\
\hline \multirow[t]{2}{*}{$\begin{array}{l}\text { Worst } \\
\text { Property scenario } \\
\text { Human scenario }\end{array}$} & $\begin{array}{l}\text { Low safety } \\
\text { Low safety } \\
\text { High safety }\end{array}$ & $\begin{array}{l}\text { Hig } \\
\text { Hig }\end{array}$ & $\begin{array}{l}\text { level of damage } \\
\text { No damage } \\
\text { level of damage }\end{array}$ & 3 & 0 & & & \\
\hline & Rural livelihood & & Rural landscape & & the family & Development & Rank & Grade \\
\hline Worst & $\begin{array}{c}33-0 \% \text { of income fr } \\
\text { the property }\end{array}$ & & Lose a lot & $33-0 \%$ & $\begin{array}{l}\text { of property in } \\
\text { he family }\end{array}$ & $\begin{array}{l}\text { More than two } \\
\text { divisions }\end{array}$ & 5 & 0 \\
\hline $\begin{array}{l}\text { Livelihood } \\
\text { scenario }\end{array}$ & $\begin{array}{l}100-67 \% \text { of income } \\
\text { the property }\end{array}$ & & Lose a lot & 33-0\% & $\begin{array}{l}\text { of property in } \\
\text { he family }\end{array}$ & $\begin{array}{l}\text { More than two } \\
\text { divisions }\end{array}$ & & \\
\hline $\begin{array}{l}\text { Landscape } \\
\text { scenario }\end{array}$ & $\begin{array}{c}33-0 \% \text { of income fr } \\
\text { the property }\end{array}$ & & Maintain & 33-0\% & $\begin{array}{l}\text { of property in } \\
\text { he family }\end{array}$ & $\begin{array}{l}\text { More than two } \\
\text { divisions }\end{array}$ & & \\
\hline $\begin{array}{l}\text { Family } \\
\text { scenario }\end{array}$ & $\begin{array}{c}33-0 \% \text { of income fr } \\
\text { the property }\end{array}$ & & Lose a lot & $\begin{array}{r}100-6 \\
\text { in }\end{array}$ & $\begin{array}{l}7 \% \text { of property } \\
\text { the family }\end{array}$ & $\begin{array}{l}\text { More than two } \\
\text { divisions }\end{array}$ & & \\
\hline $\begin{array}{l}\text { Development } \\
\text { scenario }\end{array}$ & $\begin{array}{c}33-0 \% \text { of income fr } \\
\text { the property }\end{array}$ & & Lose a lot & $33-0 \%$ & $\begin{array}{l}\text { of property in } \\
\text { he family }\end{array}$ & No divisions & & \\
\hline
\end{tabular}




\begin{tabular}{|c|c|c|c|c|c|c|c|}
\hline & Safety & Net income & Heritage & Aesthetics & Forest health & Rank & Grade \\
\hline Worst & $\begin{array}{c}\text { Low human } \\
\text { safety \& High } \\
\text { level of property } \\
\text { damage }\end{array}$ & Negative & $\begin{array}{c}\text { Lose a lot of rural } \\
\text { landscape, } 33-0 \% \text { of } \\
\text { income from the property, } \\
\text { 33-0\% of property in the } \\
\text { family, More than two } \\
\text { divisions }\end{array}$ & $\mathrm{Bad}$ & $\begin{array}{c}\text { Low native species } \\
\text { diversity, High exotic } \\
\text { species abundance, Low } \\
\text { water quality }\end{array}$ & 6 & 0 \\
\hline $\begin{array}{c}\text { Safety } \\
\text { scenario }\end{array}$ & $\begin{array}{c}\text { High human } \\
\text { safety \& No } \\
\text { property damage }\end{array}$ & Negative & $\begin{array}{l}\text { Lose a lot of rural } \\
\text { landscape, } 33-0 \% \text { of } \\
\text { income from the property, } \\
33-0 \% \text { of property in the } \\
\text { family, More than two } \\
\text { divisions }\end{array}$ & Bad & $\begin{array}{c}\text { Low native species } \\
\text { diversity, High exotic } \\
\text { species abundance, Low } \\
\text { water quality }\end{array}$ & & \\
\hline $\begin{array}{l}\text { Net income } \\
\text { scenario }\end{array}$ & $\begin{array}{c}\text { Low human } \\
\text { safety \& High } \\
\text { level of property } \\
\text { damage }\end{array}$ & Positive & $\begin{array}{l}\text { Lose a lot of rural } \\
\text { landscape, } 33-0 \% \text { of } \\
\text { income from the property, } \\
\text { 33-0\% of property in the } \\
\text { family, More than two } \\
\text { divisions }\end{array}$ & $\mathrm{Bad}$ & $\begin{array}{c}\text { Low native species } \\
\text { diversity, High exotic } \\
\text { species abundance, Low } \\
\text { water quality }\end{array}$ & & \\
\hline $\begin{array}{l}\text { Heritage } \\
\text { scenario }\end{array}$ & $\begin{array}{c}\text { Low human } \\
\text { safety \& High } \\
\text { level of property } \\
\text { damage }\end{array}$ & Negative & $\begin{array}{l}\text { Maintain rural landscape, } \\
100-67 \% \text { of income from } \\
\text { the property, } 100-67 \% \text { of } \\
\text { property in the family, No } \\
\text { divisions }\end{array}$ & $\mathrm{Bad}$ & $\begin{array}{c}\text { Low native species } \\
\text { diversity, High exotic } \\
\text { species abundance, Low } \\
\text { water quality }\end{array}$ & & \\
\hline
\end{tabular}




\begin{tabular}{|c|c|c|c|c|c|}
\hline $\begin{array}{c}\text { Forest } \\
\text { scenario }\end{array}$ & $\begin{array}{c}\text { Low human } \\
\text { safety \& High } \\
\text { level of property } \\
\text { damage }\end{array}$ & Negative & $\begin{array}{c}\text { Lose a lot of rural } \\
\text { landscape, } 33-0 \% \text { of } \\
\text { income from the property, } \\
\text { 33-0\% of property in the } \\
\text { family, More than two } \\
\text { divisions }\end{array}$ & Bad & $\begin{array}{c}\text { High native species } \\
\text { diversity, Low exotic } \\
\text { species abundance, High } \\
\text { water quality }\end{array}$ \\
\hline $\begin{array}{l}\text { Aesthetics } \\
\text { scenario }\end{array}$ & $\begin{array}{c}\text { Low human } \\
\text { safety \& High } \\
\text { level of property } \\
\text { damage }\end{array}$ & Negative & $\begin{array}{c}\text { Lose a lot of rural } \\
\text { landscape, } 33-0 \% \text { of } \\
\text { income from the property, } \\
\text { 33-0\% of property in the } \\
\text { family, More than two } \\
\text { divisions }\end{array}$ & Good & $\begin{array}{c}\text { Low native species } \\
\text { diversity, High exotic } \\
\text { species abundance, Low } \\
\text { water quality }\end{array}$ \\
\hline
\end{tabular}


Example of how ranks and grades were used to calculate objective weights.

Given these example ranks and grades, the objective of maximize water quality had a weight of 0.42 , the objective of maximize native species diversity had a weight of 0.37 , and the objective of minimize exotic species abundance had a weight of 0.21 .

\begin{tabular}{|c|c|c|c|c|c|c|}
\hline & Native species diversity & Exotic species abundance & Water quality & Rank & Grade & $\begin{array}{c}\text { Objective } \\
\text { weight }\end{array}$ \\
\hline Worst & $\begin{array}{l}\text { Large decrease in } \\
\text { native species diversity }\end{array}$ & $\begin{array}{l}\text { Large increase in } \\
\text { exotic species abundance }\end{array}$ & $\begin{array}{l}\text { Large decrease in } \\
\text { water quality }\end{array}$ & 4 & 0 & $\begin{array}{c}=0 /(80+70+40) \\
=0\end{array}$ \\
\hline Water scenario & $\begin{array}{l}\text { Large decrease in } \\
\text { native species diversity }\end{array}$ & $\begin{array}{l}\text { Large increase in } \\
\text { exotic species abundance }\end{array}$ & $\begin{array}{l}\text { Large increase in } \\
\text { water quality }\end{array}$ & 1 & 80 & $\begin{array}{c}=80 /(80+70+40) \\
=0.42\end{array}$ \\
\hline Native scenario & $\begin{array}{l}\text { Large increase in } \\
\text { native species diversity }\end{array}$ & $\begin{array}{l}\text { Large increase in } \\
\text { exotic species abundance }\end{array}$ & $\begin{array}{l}\text { Large decrease in } \\
\text { water quality }\end{array}$ & 2 & 70 & $\begin{array}{c}=70 /(80+70+40) \\
\quad=0.37\end{array}$ \\
\hline Exotic scenario & $\begin{array}{l}\text { Large decrease in } \\
\text { native species diversity }\end{array}$ & $\begin{array}{c}\text { Large decrease in } \\
\text { exotic species abundance }\end{array}$ & $\begin{array}{c}\text { Large decrease in } \\
\text { water quality }\end{array}$ & 3 & 40 & $\begin{array}{c}=40 /(80+70+40) \\
\quad=0.21\end{array}$ \\
\hline
\end{tabular}




\section{Appendix 2}

Worksheet to elicit attribute scores. Twenty owners of large, forested properties (at least 20 ha in total area with at least 4 ha of forest) in Macon County, North Carolina, participated in a structured decision making (SDM) process consisting of two series of workshops with ten landowners each. In each series, landowners evaluated what they can do to their forest to maximize the achievement of their land use objectives. After landowners identified their objectives, they created attributes to make their objectives measurable. Attributes provide the scales to measure the degree to which outcomes from a decision satisfy fundamental objectives. The landowners in an SDM series shared common objectives, but each landowner assigned their own scores to attributes. The attribute scores were elicited using this worksheet.

Instructions:

- Give each level a grade between 100 and 0

- The grade reflects how satisfied you would be with that outcome, where $100=$ completely satisfied

\begin{tabular}{l} 
Net income \\
\hline Level Grade \\
\hline Positive \\
Even \\
Negative \\
\hline
\end{tabular}

Property development

\begin{tabular}{l}
\multicolumn{1}{c}{ Level } \\
\hline No divisions \\
Up to two divisions \\
More than two divisions \\
\hline
\end{tabular}

Property in the family

\begin{tabular}{l}
\hline Level \\
\hline $100-67 \%$ of property in the family \\
$66-34 \%$ of property in the family \\
$33-0 \%$ of property in the family \\
\hline
\end{tabular}

Income from property

\begin{tabular}{|c|c|}
\hline Level & Grade \\
\hline $100-67 \%$ of income from property & \\
\hline $66-34 \%$ of income from property & \\
\hline $33-0 \%$ of income from property & \\
\hline
\end{tabular}


Rural landscape

\begin{tabular}{l}
\multicolumn{1}{c}{ Level Grade } \\
\hline Maintain \\
Lose a little \\
Lose a lot \\
\hline
\end{tabular}

Human safety

\begin{tabular}{l}
\hline \multicolumn{1}{c}{ Level } \\
\hline High safety \\
Moderate safety \\
Low safety
\end{tabular}

Property damage

\begin{tabular}{ll}
\hline Level & Grade \\
\hline No damage & \\
Low damage & \\
High damage & \\
\hline
\end{tabular}

Diversity of native species

\begin{tabular}{ll}
\hline \multicolumn{1}{c}{ Level } & Grade \\
\hline Very high & \\
Moderately high & \\
Moderately low \\
Very low
\end{tabular}

High damage
Exotic species abundance

\begin{tabular}{l}
\multicolumn{1}{c}{ Level Grade } \\
\hline High \\
Medium \\
Low
\end{tabular}

\begin{tabular}{l}
\multicolumn{2}{c}{ Water quality } \\
\hline \multicolumn{1}{c}{ Level Grade } \\
\hline High \\
Medium \\
Low \\
\hline
\end{tabular}

\begin{tabular}{l} 
Aesthetics \\
\hline \multicolumn{1}{c}{ Level Grade } \\
\hline Good \\
Bad
\end{tabular}




\section{Appendix 3}

Explanation of how expert opinion can appropriately be used in structured decision making. Twenty owners of large, forested properties (at least 20 ha in total area with at least 4 ha of forest) in Macon County, North Carolina, participated in a structured decision making (SDM) process consisting of two series of workshops with ten landowners each. In each series, landowners evaluated what they can do to their forest to maximize the achievement of their land use objectives. The decision network was populated with probabilities from experts.

Using expert opinion to generate values in a quantitative analysis may seem of questionable validity to scientists trained in controlled experiments founded on the notion of falsifiability (Gregory and Failing 2002). However, the expert opinions were elicited and used in a rigorous, transparent, and logical way (Martin et al. 2009). Also, it is important to recall the goal of SDM: to use currently available knowledge in a value-focused process to objectively evaluate decision options and identify the decision option with the greatest probability of achieving decision-makers' objectives. Often, a decision must be made regardless of the current state of knowledge, and SDM is a process to support decision-making so that underlying assumptions are made explicit, key uncertainties are identified, decision components are transparent, and, consequently, a desired outcome is more likely to be achieved (Marcot et al. 2001). Also, SDM is complimented by adaptive management in that models can be updated and decisions can be re-evaluated as more data become available (Nyberg et al. 2006, McFadden et al. 2011, Tyre and Michaels 2011). Further, the use of expert opinion is consistent with the call to integrate local knowledge in decision-making (Jasanoff 1990, Irwin and Wynne 1996, Fischer 2000, Failing et al. 2007). When more sources than journal publications are used, knowledge held by people outside of academia, such as land managers, become accessible (Johnson 1999, Raymond et al. 2010). Such an approach can increase knowledge while also cultivating inclusivity and buy-in by stakeholders (Raymond et al. 2010).

Failing, L., R. Gregory, and M. Harstone. 2007. Integrating science and local knowledge in environmental risk management: a decision-focused approach. Ecological Economics 64: 47-60.

Fischer, F. 2000. Citizens, experts and the environment: the politics of local knowledge. Duke University Press, Durham, NC, USA.

Gregory, R. and L. Failing. 2002. Using decision analysis to encourage sound deliberation: water use planning in British Columbia, Canada. Journal of Policy Analysis and Management 21(3): 492-499.

Irwin, A. and B. Wynne (eds.). 1996. Misunderstanding science?: the public reconstruction of science and technology. Cambridge University Press, Cambridge, UK.

Jasanoff, S. 1990. The fifth branch: science advisors as policymakers. Harvard University Press, Cambridge, MA, USA.

Johnson, B. L. 1999. Introduction to the special feature: adaptive management - scientifically sound, socially challenged? Ecology and Society 3(1): 10.

Marcot, B. G., R. S. Holthausen, M. G. Raphael, M. M. Rowland, M. J. Wisdom. 2001. Using Bayesian belief networks to evaluate fish and wildlife population viability under land management alternatives from an environmental impact statement. Forest Ecology and Management 153: 29-42. 
Martin, J., M. C. Runge, J. D. Nichols, B. C. Lubow, and W. L. Kendall. 2009. Structured decision making as a conceptual framework to identify thresholds for conservation and management. Ecological Applications 19(5): 1079-1090.

McFadden, J. E., T. L. Hiller, and A. J. Tyre. 2011. Evaluating the efficacy of adaptive management approaches: is there a formula for success? Journal of Environmental Management 92: 1354-1359.

Nyberg, J. B., B. G. Marcot, and R. Sulyma. 2006. Using Bayesian belief networks in adaptive management. Canadian Journal of Forest Research 36: 3104-3116.

Raymond, C. M., I. Fazey, M. S. Reed, L. C. Stringer, G. M. Robinson, A. C. Evely. 2010. Integrating local and scientific knowledge for environmental management. Journal of Environmental Management 91: 1766-1777.

Tyre, A. J. and S. Michaels. 2011. Confronting socially generated uncertainty in adaptive management. Journal of Environmental Management 92: 1365-1370. 


\begin{abstract}
Appendix 4
Questionnaires completed before and after the Bayesian decision network results were presented. Twenty owners of large, forested properties (at least 20 ha in total area with at least 4 ha of forest) in Macon County, North Carolina, participated in a structured decision making (SDM) process consisting of two series of workshops with ten landowners each. In each series, landowners evaluated what they can do to their forest to maximize the achievement of their land use objectives. A Bayesian decision network was used to evaluate which decision option was optimal or least-desirable given landowners' objectives, objective weights, and attribute scores and predictions from a model of expected outcomes from each decision option. Landowners completed one questionnaire before results from the decision network were presented to them and one questionnaire after results were presented.
\end{abstract}

\title{
Questionnaire completed before Bayesian decision network results were presented
}

Which decision option do you think will be best at meeting the objectives?

Do you think other decision options will be almost as good? Which decision options would be close alternatives?

Do you currently use one or more of the decision options we are studying? Which do you use? If the results indicate that the best decision option is not one of the decision option that you expected, would you consider re-evaluating your preferences for the decision options?

No

Most likely no

Maybe

Most likely yes

Yes

Might the results of our analysis affect how you manage your forest?

No

Most likely no

Maybe

Most likely yes

Yes

Might the results of our analysis lead you to consider discontinuing what you are currently doing to manage your forest?

No

Most likely no

Maybe

Most likely yes

Yes

Might the results of our analysis lead you to consider doing something new to manage your forest?

No

Most likely no

Maybe

Most likely yes

Yes 


\section{Questionnaire completed after Bayesian decision network results were presented}

Would you be interested in having the decision network personalized for your property and your objectives so that you can evaluate different methods to manage your forest?

(We are not able to personalize them, but we would like to gauge your interest so that, if there is a demand, perhaps someone would be interested in offering this service to landowners.)

No

Most likely no

Maybe

Most likely yes

Yes

Would you pay someone to personalize the decision network for your property and your objectives so that you can evaluate different methods to manage your forest?

No

Yes

If yes, what do you think would be a fair price?

After participating in this project, will you reconsider whether what you are currently doing to manage your forest is the best option for you?

No

Most likely no

Maybe

Most likely yes

Yes

After participating in this project, will you investigate forest management options other than the option you are currently using?

No

Most likely no

Maybe

Most likely yes

Yes

Which forest management options might you investigate?

What was your overall experience of the project?

Very good

Good

$\mathrm{OK}$

Poor

Very poor 
How well did you understand the material being presented?

Understood all of the material

Understood most of the material

Understood about half of the material

Did not understand most of the material

Did not understand any of the material

What was the most unclear, confusing, or difficult to understand?

What did you enjoy or benefit from the most?

What did you not enjoy or not benefit from?

Do you have any recommendations for us that would help us with future projects? 


\section{Appendix 5}

Objective weights provided by landowners. Twenty owners of large, forested properties (at least 20 ha in total area with at least 4 ha of forest) in Macon County, North Carolina, participated in a structured decision making (SDM) process consisting of two series of workshops ( $\mathrm{a}=$ Series $1, \mathrm{~b}=$ Series 2$)$ with ten landowners each. In each series, landowners evaluated what they can do to their forest to maximize the achievement of their land use objectives. Landowners identified first-order objectives and second-order objectives, which described components of a first-order objective, and assigned weights to the objectives that reflected their relative importance to the landowner. Each landowner completed a weight elicitation worksheet, and the number of objective weight combinations in a series depended on the number of worksheets with logically-consistent responses. A combination was made for each logicallyconsistent worksheet. Otherwise, logically-consistent responses were averaged across worksheets to create a mean combination.

\section{Table A5.1}

a)

\begin{tabular}{|c|c|c|c|}
\hline First-order objectives & Mean & Second-order objectives & Mean \\
\hline \multirow[t]{3}{*}{ Maximize forest health } & 0.33 & Minimize exotic species abundance & 0.30 \\
\hline & & Maximize water quality & 0.40 \\
\hline & & Maximize native species diversity & 0.30 \\
\hline \multirow[t]{2}{*}{ Maximize safety } & 0.25 & Maximize human safety & 0.49 \\
\hline & & Minimize property damage & 0.51 \\
\hline \multirow[t]{4}{*}{ Maximize heritage preservation } & 0.26 & Minimize future development & 0.23 \\
\hline & & Maximize percent of property in the family & 0.27 \\
\hline & & Maximize percent of income from the property & 0.21 \\
\hline & & Maximize rural landscape & 0.29 \\
\hline Maximize net income & 0.16 & & \\
\hline
\end{tabular}


b)

\begin{tabular}{lcccc}
\hline & \multicolumn{4}{c}{ Combinations } \\
First-order objectives & Mean & 1 & 2 & 3 \\
\hline Maximize forest health & 0.27 & 0.00 & 0.20 & 0.29 \\
Maximize safety & 0.33 & 0.00 & 0.20 & 0.14 \\
Maximize heritage preservation & 0.13 & 0.67 & 0.20 & 0.14 \\
Maximize net income & 0.07 & 0.00 & 0.20 & 0.14 \\
Maximize aesthetics & 0.20 & 0.33 & 0.20 & 0.29 \\
\hline
\end{tabular}

\begin{tabular}{|c|c|c|c|c|c|}
\hline \multirow[b]{2}{*}{ First-order objectives } & \multirow[b]{2}{*}{ Second-order objectives } & \multicolumn{4}{|c|}{ Combinations } \\
\hline & & Mean & 1 & 2 & 3 \\
\hline \multirow[t]{3}{*}{ Maximize forest health } & Minimize exotic species abundance & 0.23 & 0.25 & 0.00 & 0.11 \\
\hline & Maximize water quality & 0.31 & 0.50 & 0.50 & 0.44 \\
\hline & Maximize native species diversity & 0.46 & 0.25 & 0.50 & 0.44 \\
\hline \multirow[t]{2}{*}{ Maximize safety } & Maximize human safety & 0.72 & 1.00 & 1.00 & 0.67 \\
\hline & Minimize property damage & 0.28 & 0.00 & 0.00 & 0.33 \\
\hline \multirow[t]{4}{*}{ Maximize heritage preservation } & Minimize future development & 0.28 & 0.20 & 0.20 & 0.14 \\
\hline & Maximize percent of property in the family & 0.35 & 0.20 & 0.33 & 0.14 \\
\hline & Maximize percent of income from the property & 0.15 & 0.20 & 0.13 & 0.14 \\
\hline & Maximize rural landscape & 0.23 & 0.40 & 0.33 & 0.57 \\
\hline
\end{tabular}




\section{Appendix 6}

Attribute scores provided by landowners. Twenty owners of large, forested properties (at least 20 ha in total area with at least 4 ha of forest) in Macon County, North Carolina, participated in a structured decision making (SDM) process consisting of two series of workshops ( $\mathrm{a}=$ Series $1, \mathrm{~b}=$ Series 2$)$ with ten landowners each. In each series, landowners assigned scores reflecting their satisfaction were the attribute level to occur. Each landowner completed an attribute score elicitation worksheet, and the number of attribute score combinations in a series depended on the number of worksheets with logically-consistent responses. A combination was made for each logically-consistent worksheet. Otherwise, logically-consistent responses were averaged across worksheets to create a mean combination.

Table A6.1

a)

\begin{tabular}{llcccc}
\hline \hline \multirow{2}{*}{ Objective } & & \multicolumn{3}{c}{ Combinations } \\
\hline Exotic species abundance & Attribute level & Mean & 1 & 2 & 3 \\
& Low & 100 & 100 & 90 & 100 \\
Water quality & Medium & 57.5 & 50 & 37.5 & 70 \\
& High & 13.33 & 0 & 0 & 40 \\
& High & 100 & 100 & 100 & 100 \\
Native species diversity & Medium & 52 & 72.5 & 37.5 & 70 \\
& Low & 15 & 0 & 0 & 50 \\
& Very high & 100 & 90 & 100 & 100 \\
& Moderately high & 69 & 80 & 75 & 80 \\
Human safety & Moderately low & 40 & 70 & 25 & 60 \\
& Very low & 20 & 40 & 10 & 20 \\
& High & 100 & 100 & 100 & 100 \\
Property damage & Moderate & 67.5 & 90 & 0 & 70 \\
& Low & 28.75 & 75 & 0 & 50 \\
& None & 100 & 100 & 100 & 100 \\
& Low & 50 & 75 & 60 & 50 \\
& High & 19 & 50 & 25 & 20
\end{tabular}




\begin{tabular}{llcccc} 
Future development & None & 100 & 100 & 100 & 100 \\
& Up to two divisions & 55 & 75 & 50 & 70 \\
& More than two divisions & 23.6 & 50 & 25 & 50 \\
Percent of property in the family & $100-67 \%$ of property & 95 & 100 & 80 & 100 \\
& $66-34 \%$ of property & 53.75 & 75 & 40 & 80 \\
& $33-0 \%$ of property & 38.75 & 25 & 0 & 20 \\
Percent of income from the property & $100-67 \%$ of income & 97.5 & 100 & 75 & 100 \\
& $66-34 \%$ of income & 78.75 & 90 & 50 & 80 \\
& 33-0\% of income & 55 & 80 & 25 & 60 \\
Rural landscape & Maintain & 100 & 100 & 75 & 100 \\
\multirow{5}{*}{ Net income } & Lose a little & 65 & 75 & 50 & 80 \\
& Lose a lot & 24 & 25 & 25 & 50 \\
& Positive & 100 & 100 & 100 & 100 \\
& Even & 63 & 90 & 50 & 70 \\
& Negative & 18 & 80 & 25 & 60 \\
\hline
\end{tabular}


b)

\begin{tabular}{|c|c|c|c|c|c|c|c|}
\hline \multirow[b]{2}{*}{ Objective } & \multirow[b]{2}{*}{ Attribute level } & \multicolumn{6}{|c|}{ Combinations } \\
\hline & & Mean & 1 & 2 & 3 & 4 & 5 \\
\hline \multirow[t]{2}{*}{ Exotic species abundance } & Low & 60 & 100 & 80 & 100 & 100 & 100 \\
\hline & High & 20 & 0 & 20 & 0 & 0 & 0 \\
\hline \multirow[t]{2}{*}{ Water quality } & High & 93 & 100 & 80 & 100 & 100 & 100 \\
\hline & Low & 7 & 0 & 10 & 0 & 0 & 0 \\
\hline \multirow[t]{2}{*}{ Native species diversity } & High & 97 & 50 & 90 & 100 & 100 & 100 \\
\hline & Low & 3 & 0 & 20 & 0 & 0 & 0 \\
\hline \multirow[t]{3}{*}{ Human safety } & High & 100 & 20 & 100 & 100 & 100 & 90 \\
\hline & Moderate & 14 & 10 & 50 & 10 & 5 & 10 \\
\hline & Low & 7 & 0 & 0 & 0 & 0 & 0 \\
\hline \multirow[t]{3}{*}{ Property damage } & None & 97 & 100 & 90 & 100 & 100 & 95 \\
\hline & Low & 12 & 80 & 40 & 80 & 20 & 5 \\
\hline & High & 0 & 75 & 10 & 10 & 0 & 0 \\
\hline \multirow[t]{2}{*}{ Future development } & None & 97 & 90 & 50 & 100 & 100 & 100 \\
\hline & At least one division & 30 & 2 & 20 & 10 & 10 & 0 \\
\hline \multirow[t]{2}{*}{ Proportion of property in the family } & $100-51 \%$ of property & 97 & 30 & 80 & 90 & 80 & 50 \\
\hline & $50-0 \%$ of property & 28 & 30 & 50 & 10 & 20 & 50 \\
\hline \multirow[t]{2}{*}{ Proportion of income from the property } & $100-51 \%$ of income & 50 & 10 & 50 & 70 & 60 & 70 \\
\hline & $50-0 \%$ of income & 50 & 10 & 50 & 50 & 10 & 30 \\
\hline \multirow[t]{2}{*}{ Rural landscape } & Maintain & 92 & 100 & 60 & 100 & 100 & 100 \\
\hline & Lose & 0 & 0 & 0 & 0 & 0 & 0 \\
\hline \multirow[t]{3}{*}{ Net income } & Positive & 100 & 10 & 50 & 100 & 60 & 80 \\
\hline & Even & 85 & 0 & 30 & 100 & 50 & 20 \\
\hline & Negative & 25 & 0 & 10 & 50 & 40 & 0 \\
\hline \multirow[t]{2}{*}{ Aesthetics } & Good & 83 & 100 & 90 & 100 & 100 & 100 \\
\hline & Bad & 3 & 0 & 20 & 0 & 0 & 0 \\
\hline
\end{tabular}




\section{Appendix 7}

Explanation of decision options. Twenty owners of large, forested properties (at least 20 ha in total area with at least 4 ha of forest) in Macon County, North Carolina, participated in a structured decision making (SDM) process consisting of two series of workshops with ten landowners each. In each series, landowners evaluated what they can do to their forest to maximize the achievement of their land use objectives. Landowners identified decision options that could contribute to fulfilling their objectives. These decision options are described here.

Property enrolled in the Present-Use Value (PUV) program is taxed at the present-use value rather than at the full market value. In general, forestland can be enrolled in the PUV program if there is at least one tract that is at least 8 ha in area and forestland management complies with a written sound management plan for commercial timber production. Then the enrolled forestland is assessed at its current use of commercially growing trees. Because land is assessed at a lower value under the PUV program, property taxes on enrolled land are lower than they would be at full market value. We evaluated the decision options involving the PUV program assuming that the landowner would have a forest management plan developed and timber sales administered by Forest Stewards in Jackson County, North Carolina, or a comparable organization. During crown thinning, the best trees are left about $12 \mathrm{~m}$ apart, which reduces competition among trees and facilitates growth. With group selection, all trees within 0.2-0.4 ha patches are cut, and in a shelterwood harvest with residual trees, trees are left 18-30.5 $\mathrm{m}$ apart to serve as seed trees.

A conservation easement is a legal agreement in which a property owner restricts some of their ownership rights. For example, development rights may be restricted in a conservation easement so that historic sites or ecological attributes will be protected. The landowner retains ownership of the property and can sell or bequeath the property, but the terms of the conservation easement continue with the property title for all future owners. Qualifying landowners may receive federal income and capital gains tax deductions, state income tax credits, lower property taxes, and/or lower estate taxes. We evaluated the decision options involving conservation easements assuming that the landowner would donate a permanent easement through the Land Trust for the Little Tennessee (LTLT) in Macon County, North Carolina, or a similar organization. For the past several years, funds have not been available to compensate landowners in Macon County for establishing permanent conservation easements. 


\begin{abstract}
Appendix 8
Conditional probabilities. Twenty owners of large, forested properties (at least 20 ha in total area with at least 4 ha of forest) in Macon County, North Carolina, participated in a structured decision making (SDM) process consisting of two series of workshops with ten landowners each. In each series, landowners evaluated what they can do to their forest to maximize the achievement of their land use objectives. Forest management decision options were evaluated through a decision network that predicted expected outcomes from each decision option. Conditional probabilities describing the probability of outcomes given states were required to analyze the decision network. Scientific experts completed the conditional probability tables related to shade-intolerant tree abundance, exotic species abundance, the conservation value of the forest for herpetofauna, the conservation value of the forest for birds, water quality, erosion severity, fire severity, human safety, property damage, and net income. The landowners completed the conditional probability tables related to maintaining a rural landscape, keeping the property in the family, minimizing development, and aesthetics. If the conditional probability tables differ between the two series of discussion meetings, the series is indicated above the table.
\end{abstract}

Table A8.1

\begin{tabular}{lcccc}
\hline \hline & Expert & $\begin{array}{c}\text { High severity of } \\
\text { fire }\end{array}$ & $\begin{array}{c}\text { Low severity of } \\
\text { fire }\end{array}$ & No fire \\
\hline No modification & 1 & 0.01 & 0.04 & 0.95 \\
No modification & 2 & 0 & 0 & 1 \\
Personal use & 1 & 0.01 & 0.04 & 0.95 \\
Personal use & 2 & 0 & 0 & 1 \\
Thinning & 1 & 0.01 & 0.04 & 0.95 \\
Thinning & 2 & 0 & 0 & 1 \\
Group selection & 1 & 0.01 & 0.04 & 0.95 \\
Group selection & 2 & 0 & 0 & 1 \\
Shelterwood & 1 & 0.01 & 0.04 & 0.95 \\
Shelterwood & 2 & 0 & 0 & 1 \\
Easement with no modification & 1 & 0.01 & 0.04 & 0.95 \\
Easement with no modification & 2 & 0 & 0 & 1 \\
Easement with personal use & 1 & 0.01 & 0.04 & 0.95 \\
Easement with personal use & 2 & 0 & 0 & 1 \\
Easement with thinning & 1 & 0.01 & 0.04 & 0.95 \\
Easement with thinning & 2 & 0 & 0 & 1 \\
Easement with group selection & 1 & 0.01 & 0.04 & 0.95 \\
Easement with group selection & 2 & 0 & 0 & 1 \\
Easement with shelterwood & 1 & 0.01 & 0.04 & 0.95 \\
Easement with shelterwood & 2 & 0 & 0 & 1
\end{tabular}


Sell 5 acres, remainder personal use

Sell 5 acres, remainder

personal use 
Table A8.2

\begin{tabular}{|c|c|c|c|c|}
\hline Decision option & Expert & $\begin{array}{l}\text { High severity } \\
\text { of erosion }\end{array}$ & $\begin{array}{l}\text { Medium severity } \\
\text { of erosion }\end{array}$ & $\begin{array}{l}\text { Low severity } \\
\text { of erosion }\end{array}$ \\
\hline No modification & 1 & 0 & 0.3 & 0.7 \\
\hline No modification & 2 & 0.05 & 0.35 & 0.6 \\
\hline Personal use & 1 & 0 & 0.3 & 0.7 \\
\hline Personal use & 2 & 0.1 & 0.4 & 0.5 \\
\hline Thinning & 1 & 0 & 0.3 & 0.7 \\
\hline Thinning & 2 & 0.15 & 0.45 & 0.4 \\
\hline Group selection & 1 & 0.1 & 0.3 & 0.6 \\
\hline Group selection & 2 & 0.2 & 0.45 & 0.35 \\
\hline Shelterwood & 1 & 0.1 & 0.3 & 0.6 \\
\hline Shelterwood & 2 & 0.22 & 0.43 & 0.35 \\
\hline $\begin{array}{l}\text { Easement with no } \\
\text { modification } \\
\text { Easement with no }\end{array}$ & 1 & 0 & 0.3 & 0.7 \\
\hline $\begin{array}{l}\text { Easement with no } \\
\text { modification } \\
\text { Easement with personal }\end{array}$ & 2 & 0.05 & 0.35 & 0.6 \\
\hline $\begin{array}{l}\text { use } \\
\text { Easement with personal }\end{array}$ & 1 & 0 & 0.3 & 0.7 \\
\hline use & 2 & 0.1 & 0.4 & 0.5 \\
\hline Easement with thinning & 1 & 0 & 0.3 & 0.7 \\
\hline $\begin{array}{l}\text { Easement with thinning } \\
\text { Easement with group }\end{array}$ & 2 & 0.15 & 0.45 & 0.4 \\
\hline $\begin{array}{l}\text { selection } \\
\text { Easement with group }\end{array}$ & 1 & 0.1 & 0.3 & 0.6 \\
\hline selection & 2 & 0.2 & 0.45 & 0.35 \\
\hline Easement with shelterwood & 1 & 0.1 & 0.3 & 0.6 \\
\hline $\begin{array}{l}\text { Easement with shelterwood } \\
\text { Sell } 5 \text { acres, remainder }\end{array}$ & 2 & 0.22 & 0.43 & 0.35 \\
\hline $\begin{array}{l}\text { personal use } \\
\text { Sell } 5 \text { acres, remainder }\end{array}$ & 1 & 0.5 & 0.3 & 0.2 \\
\hline personal use & 2 & 0.22 & 0.43 & 0.35 \\
\hline
\end{tabular}


Table A8.3

\begin{tabular}{llcccc}
\hline \hline & & & $\begin{array}{c}\text { No } \\
\text { property } \\
\text { damage }\end{array}$ & $\begin{array}{c}\text { Low } \\
\text { property } \\
\text { damage }\end{array}$ & $\begin{array}{c}\text { High } \\
\text { property } \\
\text { damage }\end{array}$ \\
\hline High severity & High severity & 1 & 0 & 0.2 & 0.8 \\
High severity & High severity & 2 & 0.2 & 0.6 & 0.2 \\
High severity & Low severity & 1 & 0 & 0.3 & 0.7 \\
High severity & Low severity & 2 & 0.4 & 0.5 & 0.1 \\
High severity & None & 1 & 0 & 0.3 & 0.7 \\
High severity & None & 2 & 0.55 & 0.4 & 0.05 \\
Medium severity & High severity & 1 & 0 & 0.4 & 0.6 \\
Medium severity & High severity & 2 & 0.3 & 0.55 & 0.15 \\
Medium severity & Low severity & 1 & 0 & 0.5 & 0.5 \\
Medium severity & Low severity & 2 & 0.5 & 0.45 & 0.05 \\
Medium severity & None & 1 & 0 & 0.5 & 0.5 \\
Medium severity & None & 2 & 0.65 & 0.35 & 0 \\
Low severity & High severity & 1 & 0.15 & 0.5 & 0.35 \\
Low severity & High severity & 2 & 0.3 & 0.55 & 0.15 \\
Low severity & Low severity & 1 & 0.25 & 0.5 & 0.25 \\
Low severity & Low severity & 2 & 0.85 & 0.1 & 0.05 \\
Low severity & None & 1 & 0.25 & 0.5 & 0.25 \\
Low severity & None & 2 & 1 & 0 & 0 \\
\hline
\end{tabular}


Table A8.4

\begin{tabular}{llcccc}
\hline \hline Erosion severity & Fire severity & Expert & $\begin{array}{c}\text { High human } \\
\text { safety }\end{array}$ & $\begin{array}{c}\text { Moderate } \\
\text { human safety }\end{array}$ & $\begin{array}{c}\text { Low human } \\
\text { safety }\end{array}$ \\
\hline High severity & High severity & 1 & 0 & 0.2 & 0.8 \\
High severity & High severity & 2 & 0.2 & 0.6 & 0.2 \\
High severity & Low severity & 1 & 0 & 0.3 & 0.7 \\
High severity & Low severity & 2 & 0.4 & 0.5 & 0.1 \\
High severity & None & 1 & 0 & 0.3 & 0.7 \\
High severity & None & 2 & 0.55 & 0.4 & 0.05 \\
Medium severity & High severity & 1 & 0 & 0.4 & 0.6 \\
Medium severity & High severity & 2 & 0.3 & 0.55 & 0.15 \\
Medium severity & Low severity & 1 & 0 & 0.5 & 0.5 \\
Medium severity & Low severity & 2 & 0.5 & 0.45 & 0.05 \\
Medium severity & None & 1 & 0 & 0.5 & 0.5 \\
Medium severity & None & 2 & 0.65 & 0.35 & 0 \\
Low severity & High severity & 1 & 0.15 & 0.5 & 0.35 \\
Low severity & High severity & 2 & 0.3 & 0.55 & 0.15 \\
Low severity & Low severity & 1 & 0.25 & 0.5 & 0.25 \\
Low severity & Low severity & 2 & 0.85 & 0.1 & 0.05 \\
Low severity & None & 1 & 0.25 & 0.5 & 0.25 \\
Low severity & None & 2 & 1 & 0 & 0 \\
\hline
\end{tabular}


Table A8.5

\begin{tabular}{|c|c|c|c|c|}
\hline Decision & Expert & $\begin{array}{l}\text { Negative } \\
\text { net income }\end{array}$ & $\begin{array}{l}\text { Even net } \\
\text { income }\end{array}$ & $\begin{array}{l}\text { Positive net } \\
\text { income }\end{array}$ \\
\hline No modification & 1 & 1 & 0 & 0 \\
\hline No modification & 2 & 1 & 0 & 0 \\
\hline No modification & 3 & 1 & 0 & 0 \\
\hline Personal use & 1 & 1 & 0 & 0 \\
\hline Personal use & 2 & 1 & 0 & 0 \\
\hline Personal use & 3 & 1 & 0 & 0 \\
\hline Thinning & 1 & 0.33 & 0.33 & 0.34 \\
\hline Thinning & 2 & 0.33 & 0.33 & 0.34 \\
\hline Thinning & 3 & 0.33 & 0.33 & 0.34 \\
\hline Group selection & 1 & 0.2 & 0.4 & 0.4 \\
\hline Group selection & 2 & 0.2 & 0.4 & 0.4 \\
\hline Group selection & 3 & 0.2 & 0.4 & 0.4 \\
\hline Shelterwood & 1 & 0.1 & 0.3 & 0.6 \\
\hline Shelterwood & 2 & 0.1 & 0.3 & 0.6 \\
\hline Shelterwood & 3 & 0.1 & 0.3 & 0.6 \\
\hline Easement with no modification & 1 & 1 & 0 & 0 \\
\hline Easement with no modification & 2 & 1 & 0 & 0 \\
\hline Easement with no modification & 3 & 1 & 0 & 0 \\
\hline Easement with personal use & 1 & 1 & 0 & 0 \\
\hline Easement with personal use & 2 & 1 & 0 & 0 \\
\hline Easement with personal use & 3 & 1 & 0 & 0 \\
\hline Easement with thinning & 1 & 0.4 & 0.4 & 0.2 \\
\hline Easement with thinning & 2 & 0.2 & 0.2 & 0.6 \\
\hline Easement with thinning & 3 & 0.9 & 0.1 & 0 \\
\hline Easement with group selection & 1 & 0.2 & 0.3 & 0.5 \\
\hline Easement with group selection & 2 & 0.15 & 0.15 & 0.7 \\
\hline Easement with group selection & 3 & 0.75 & 0.2 & 0.05 \\
\hline Easement with shelterwood & 1 & 0 & 0 & 1 \\
\hline Easement with shelterwood & 2 & 0.1 & 0.1 & 0.8 \\
\hline $\begin{array}{l}\text { Easement with shelterwood } \\
\text { Sell } 5 \text { acres, remainder personal }\end{array}$ & 3 & 0.6 & 0.3 & 0.1 \\
\hline $\begin{array}{l}\text { use } \\
\text { uses, remainuer personal }\end{array}$ & 1 & 0 & 0 & 1 \\
\hline Sell 5 acres, remainder personal & 2 & 0.05 & 0.1 & 0.85 \\
\hline $\begin{array}{l}\text { Sell } 5 \text { acres, remainder personal } \\
\text { use }\end{array}$ & 3 & 0.33 & 0.34 & 0.33 \\
\hline
\end{tabular}


Table A8.6

Series 1

\begin{tabular}{|c|c|c|c|c|}
\hline Net income & \multicolumn{2}{|c|}{$\begin{array}{c}100-67 \% \text { of property in } \\
\text { the family }\end{array}$} & $\begin{array}{c}66-34 \% \text { of property in } \\
\text { the family }\end{array}$ & $\begin{array}{c}33-0 \% \text { of property in } \\
\text { the family }\end{array}$ \\
\hline Positive & \multicolumn{2}{|c|}{1} & 0 & 0 \\
\hline Even & \multicolumn{2}{|c|}{0.8} & 0.1 & 0.1 \\
\hline Negative & \multicolumn{2}{|c|}{0.1} & 0.4 & 0.5 \\
\hline \multicolumn{5}{|l|}{ Series 2} \\
\hline Net income & Aesthetics & \multicolumn{2}{|c|}{$100-51 \%$ of property in family } & $\%$ of property in family \\
\hline Positive & Good & \multicolumn{2}{|c|}{0.9} & 0.1 \\
\hline Positive & Bad & \multicolumn{2}{|r|}{0.7} & 0.3 \\
\hline Even & Good & \multicolumn{2}{|r|}{0.8} & 0.2 \\
\hline Even & Bad & \multicolumn{2}{|r|}{0.4} & 0.6 \\
\hline Negative & Good & \multicolumn{2}{|r|}{0.6} & 0.4 \\
\hline Negative & Bad & \multicolumn{2}{|r|}{0.1} & 0.9 \\
\hline
\end{tabular}


Table A8.7

Series 1

\begin{tabular}{|c|c|c|c|c|}
\hline \multicolumn{2}{|l|}{ Decision option } & $\begin{array}{l}\text { Maintain rural } \\
\text { landscape }\end{array}$ & $\begin{array}{c}\text { Lose a little } \\
\text { rural } \\
\text { landscape }\end{array}$ & $\begin{array}{c}\text { Lose a lot of } \\
\text { rural } \\
\text { landscape }\end{array}$ \\
\hline \multicolumn{2}{|l|}{ No modification } & 1 & 0 & 0 \\
\hline \multicolumn{2}{|l|}{ Personal use } & 0.9 & 0.1 & 0 \\
\hline \multicolumn{2}{|l|}{ Thinning } & 0.9 & 0.1 & 0 \\
\hline \multicolumn{2}{|l|}{ Group selection } & 0.8 & 0.2 & 0 \\
\hline \multicolumn{2}{|l|}{ Shelterwood } & 0.7 & 0.3 & 0 \\
\hline \multicolumn{2}{|c|}{ Easement with no modification } & 1 & 0 & 0 \\
\hline \multicolumn{2}{|c|}{ Easement with personal use } & 1 & 0 & 0 \\
\hline \multicolumn{2}{|c|}{ Easement with thinning } & 0.9 & 0.1 & 0 \\
\hline \multicolumn{2}{|c|}{ Easement with group selection } & 0.8 & 0.2 & 0 \\
\hline \multicolumn{2}{|c|}{$\begin{array}{l}\text { Easement with shelterwood } \\
\text { Sell } 5 \text { acres, remainder personal }\end{array}$} & 0.7 & 0.3 & 0 \\
\hline \multicolumn{2}{|c|}{ use } & 0.2 & 0.6 & 0.2 \\
\hline \multicolumn{5}{|l|}{ Series 2} \\
\hline Income from property & \multicolumn{2}{|c|}{ Future development } & $\begin{array}{l}\text { tain rural } \\
\text { idscape }\end{array}$ & $\begin{array}{l}\text { Lose rural } \\
\text { landscape }\end{array}$ \\
\hline $100-51 \%$ of income & \multicolumn{2}{|c|}{ No division } & 0.8 & 0.2 \\
\hline $100-51 \%$ of income & \multicolumn{2}{|c|}{ At least one division } & 0.6 & 0.4 \\
\hline $50-0 \%$ of income & \multicolumn{2}{|c|}{ No division } & 0.7 & 0.3 \\
\hline $50-0 \%$ of income & \multicolumn{2}{|c|}{ At least one division } & 0.25 & 0.75 \\
\hline
\end{tabular}


Table A8.8

Series 1

\begin{tabular}{lccc}
\hline Net income & No division & Up to two division & More than two divisions \\
\hline Positive & 0.8 & 0.2 & 0 \\
Even & 0.4 & 0.4 & 0.2 \\
Negative & 0 & 0.5 & 0.5 \\
\hline
\end{tabular}

Series 2

\begin{tabular}{lcc}
\hline \hline Net income & No division & At least one division \\
\hline Positive & 0.9 & 0.1 \\
Even & 0.75 & 0.25 \\
Negative & 0.1 & 0.9 \\
\hline
\end{tabular}

Table A8.9

\begin{tabular}{lllcc}
\hline \hline Rural landscape & Native diversity & Water quality & Good aesthetics & Bad aesthetics \\
\hline Maintain & High & Low & 0.3 & 0.7 \\
Maintain & High & High & 1 & 0 \\
Maintain & Low & Low & 0.1 & 0.9 \\
Maintain & Low & High & 0.7 & 0.3 \\
Lose & High & Low & 0.2 & 0.8 \\
Lose & High & High & 0.8 & 0.2 \\
Lose & Low & Low & 0 & 1 \\
Lose & Low & High & 0.2 & 0.8 \\
\hline
\end{tabular}


Table A8.10

Series 1

\begin{tabular}{|c|c|c|c|c|}
\hline Decision option & Expert & $\begin{array}{l}\text { Low water } \\
\text { quality }\end{array}$ & $\begin{array}{c}\text { Medium } \\
\text { water quality }\end{array}$ & $\begin{array}{c}\text { High water } \\
\text { quality }\end{array}$ \\
\hline No modification & 1 & 0 & 0.3 & 0.7 \\
\hline No modification & 2 & 0.05 & 0.35 & 0.6 \\
\hline No modification & 3 & 0.03 & 0.07 & 0.9 \\
\hline Personal use & 1 & 0 & 0.3 & 0.7 \\
\hline Personal use & 2 & 0.1 & 0.4 & 0.5 \\
\hline Personal use & 3 & 0.05 & 0.1 & 0.85 \\
\hline Thinning & 1 & 0 & 0.3 & 0.7 \\
\hline Thinning & 2 & 0.15 & 0.45 & 0.4 \\
\hline Thinning & 3 & 0.1 & 0.15 & 0.75 \\
\hline Group selection & 1 & 0.1 & 0.3 & 0.6 \\
\hline Group selection & 2 & 0.2 & 0.45 & 0.35 \\
\hline Group selection & 3 & 0.15 & 0.35 & 0.5 \\
\hline Shelterwood & 1 & 0.1 & 0.3 & 0.6 \\
\hline Shelterwood & 2 & 0.22 & 0.43 & 0.35 \\
\hline Shelterwood & 3 & 0.25 & 0.35 & 0.4 \\
\hline Easement with no modification & 1 & 0 & 0.3 & 0.7 \\
\hline Easement with no modification & 2 & 0.05 & 0.35 & 0.6 \\
\hline Easement with no modification & 3 & 0.03 & 0.07 & 0.9 \\
\hline Easement with personal use & 1 & 0 & 0.3 & 0.7 \\
\hline Easement with personal use & 2 & 0.1 & 0.4 & 0.5 \\
\hline Easement with personal use & 3 & 0.05 & 0.1 & 0.85 \\
\hline Easement with thinning & 1 & 0 & 0.3 & 0.7 \\
\hline Easement with thinning & 2 & 0.15 & 0.45 & 0.4 \\
\hline Easement with thinning & 3 & 0.1 & 0.15 & 0.75 \\
\hline Easement with group selection & 1 & 0.1 & 0.3 & 0.6 \\
\hline Easement with group selection & 2 & 0.2 & 0.45 & 0.35 \\
\hline Easement with group selection & 3 & 0.15 & 0.35 & 0.5 \\
\hline Easement with shelterwood & 1 & 0.1 & 0.3 & 0.6 \\
\hline Easement with shelterwood & 2 & 0.22 & 0.43 & 0.35 \\
\hline $\begin{array}{l}\text { Easement with shelterwood } \\
\text { Sell } 5 \text { acres, remainder personal }\end{array}$ & 3 & 0.25 & 0.35 & 0.4 \\
\hline $\begin{array}{l}\text { use } \\
\text { Sell } 5 \text { acres, remainder personal }\end{array}$ & 1 & 0.5 & 0.3 & 0.2 \\
\hline $\begin{array}{l}\text { use } \\
\text { Sell } 5 \text { acres, remainder personal }\end{array}$ & 2 & 0.22 & 0.43 & 0.35 \\
\hline use & 3 & 0.08 & 0.12 & 0.8 \\
\hline
\end{tabular}


Series 2

\begin{tabular}{|c|c|c|c|}
\hline Decision option & Expert & $\begin{array}{l}\text { Low water } \\
\text { quality }\end{array}$ & High water quality \\
\hline No modification & 1 & 0 & 1 \\
\hline No modification & 2 & 0.225 & 0.775 \\
\hline No modification & 3 & 0.065 & 0.935 \\
\hline Personal use & 1 & 0 & 1 \\
\hline Personal use & 2 & 0.3 & 0.7 \\
\hline Personal use & 3 & 0.1 & 0.9 \\
\hline Thinning & 1 & 0 & 1 \\
\hline Thinning & 2 & 0.375 & 0.625 \\
\hline Thinning & 3 & 0.175 & 0.825 \\
\hline Group selection & 1 & 0.25 & 0.75 \\
\hline Group selection & 2 & 0.425 & 0.575 \\
\hline Group selection & 3 & 0.325 & 0.675 \\
\hline Shelterwood & 1 & 0.25 & 0.75 \\
\hline Shelterwood & 2 & 0.435 & 0.565 \\
\hline Shelterwood & 3 & 0.425 & 0.575 \\
\hline Easement with no modification & 1 & 0 & 1 \\
\hline Easement with no modification & 2 & 0.225 & 0.775 \\
\hline Easement with no modification & 3 & 0.065 & 0.935 \\
\hline Easement with personal use & 1 & 0 & 1 \\
\hline Easement with personal use & 2 & 0.3 & 0.7 \\
\hline Easement with personal use & 3 & 0.1 & 0.9 \\
\hline Easement with thinning & 1 & 0 & 1 \\
\hline Easement with thinning & 2 & 0.375 & 0.625 \\
\hline Easement with thinning & 3 & 0.175 & 0.825 \\
\hline Easement with group selection & 1 & 0.25 & 0.75 \\
\hline Easement with group selection & 2 & 0.425 & 0.575 \\
\hline Easement with group selection & 3 & 0.325 & 0.675 \\
\hline Easement with shelterwood & 1 & 0.25 & 0.75 \\
\hline Easement with shelterwood & 2 & 0.435 & 0.565 \\
\hline Easement with shelterwood & 3 & 0.425 & 0.575 \\
\hline Sell 5 acres, remainder personal use & 1 & 0.65 & 0.35 \\
\hline Sell 5 acres, remainder personal use & 2 & 0.435 & 0.565 \\
\hline Sell 5 acres, remainder personal use & 3 & 0.14 & 0.86 \\
\hline
\end{tabular}


Table A8.11

Series 1

\begin{tabular}{|c|c|c|c|c|}
\hline Decision option & Expert & $\begin{array}{c}\text { High } \\
\text { abundance } \\
\text { of exotic } \\
\text { species } \\
\end{array}$ & $\begin{array}{c}\text { Medium } \\
\text { abundance } \\
\text { of exotic } \\
\text { species } \\
\end{array}$ & $\begin{array}{c}\text { Low } \\
\text { abundance } \\
\text { of exotic } \\
\text { species }\end{array}$ \\
\hline No modification & 1 & 0 & 0.3 & 0.7 \\
\hline No modification & 2 & 0.2 & 0.3 & 0.5 \\
\hline Personal use & 1 & 0 & 0.3 & 0.7 \\
\hline Personal use & 2 & 0.25 & 0.35 & 0.4 \\
\hline Thinning & 1 & 0 & 0.3 & 0.7 \\
\hline Thinning & 2 & 0.3 & 0.4 & 0.3 \\
\hline Group selection & 1 & 0.1 & 0.3 & 0.6 \\
\hline Group selection & 2 & 0.35 & 0.4 & 0.25 \\
\hline Shelterwood & 1 & 0.15 & 0.25 & 0.6 \\
\hline Shelterwood & 2 & 0.37 & 0.38 & 0.25 \\
\hline Easement with no modification & 1 & 0 & 0.3 & 0.7 \\
\hline Easement with no modification & 2 & 0.2 & 0.3 & 0.5 \\
\hline Easement with personal use & 1 & 0 & 0.3 & 0.7 \\
\hline Easement with personal use & 2 & 0.25 & 0.35 & 0.4 \\
\hline Easement with thinning & 1 & 0 & 0.3 & 0.7 \\
\hline Easement with thinning & 2 & 0.3 & 0.4 & 0.3 \\
\hline Easement with group selection & 1 & 0.1 & 0.3 & 0.6 \\
\hline Easement with group selection & 2 & 0.35 & 0.4 & 0.25 \\
\hline Easement with shelterwood & 1 & 0.15 & 0.25 & 0.6 \\
\hline $\begin{array}{l}\text { Easement with shelterwood } \\
\text { Sell } 5 \text { acres, remainder personal }\end{array}$ & 2 & 0.37 & 0.38 & 0.25 \\
\hline $\begin{array}{l}\text { use } \\
\text { Sell } 5 \text { acres, remainder personal }\end{array}$ & 1 & 0.5 & 0.3 & 0.2 \\
\hline use & 2 & 0.37 & 0.38 & 0.25 \\
\hline
\end{tabular}


Series 2

\begin{tabular}{lccc}
\hline \hline Decision option & Expert & $\begin{array}{c}\text { High abundance } \\
\text { of exotic species }\end{array}$ & $\begin{array}{c}\text { Low abundance } \\
\text { of exotic species }\end{array}$ \\
\hline No modification & 1 & 0 & 1 \\
No modification & 2 & 0.35 & 0.65 \\
Personal use & 1 & 0 & 1 \\
Personal use & 2 & 0.425 & 0.575 \\
Thinning & 1 & 0 & 1 \\
Thinning & 2 & 0.5 & 0.5 \\
Group selection & 1 & 0.25 & 0.75 \\
Group selection & 2 & 0.55 & 0.45 \\
Shelterwood & 1 & 0.275 & 0.725 \\
Shelterwood & 2 & 0.56 & 0.44 \\
Easement with no modification & 1 & 0 & 1 \\
Easement with no modification & 2 & 0.35 & 0.65 \\
Easement with personal use & 1 & 0 & 1 \\
Easement with personal use & 2 & 0.425 & 0.575 \\
Easement with thinning & 1 & 0 & 1 \\
Easement with thinning & 2 & 0.5 & 0.5 \\
Easement with group selection & 1 & 0.25 & 0.75 \\
Easement with group selection & 2 & 0.55 & 0.45 \\
Easement with shelterwood & 1 & 0.275 & 0.725 \\
Easement with shelterwood & 2 & 0.56 & 0.44 \\
Sell 5 acres, remainder personal use & 1 & 0.65 & 0.35 \\
Sell 5 acres, remainder personal use & 2 & 0.56 & 0.44 \\
\hline
\end{tabular}


Table A8.12

\begin{tabular}{lcccc}
\hline \hline & Expert & $\begin{array}{c}\text { Less } \\
\text { conservation } \\
\text { value for } \\
\text { birds }\end{array}$ & $\begin{array}{c}\text { Equal } \\
\text { conservation } \\
\text { value for birds }\end{array}$ & $\begin{array}{c}\text { More } \\
\text { conservation } \\
\text { value for } \\
\text { birds }\end{array}$ \\
\hline Nocision modification & 1 & 0 & 1 & 0 \\
No modification & 2 & 0 & 1 & 0 \\
Personal use & 1 & 0.15 & 0.75 & 0.1 \\
Personal use & 2 & 0.1 & 0.9 & 0 \\
Thinning & 1 & 0.25 & 0.5 & 0.25 \\
Thinning & 2 & 0.2 & 0.8 & 0 \\
Group selection & 1 & 0.65 & 0.2 & 0.15 \\
Group selection & 2 & 0.3 & 0.7 & 0 \\
Shelterwood & 1 & 0.8 & 0.15 & 0.05 \\
Shelterwood & 2 & 0.4 & 0.6 & 0 \\
Easement with no modification & 1 & 0 & 1 & 0 \\
Easement with no modification & 2 & 0 & 1 & 0 \\
Easement with personal use & 1 & 0.15 & 0.75 & 0.1 \\
Easement with personal use & 2 & 0.1 & 0.9 & 0 \\
Easement with thinning & 1 & 0.25 & 0.5 & 0.25 \\
Easement with thinning & 2 & 0.2 & 0.8 & 0 \\
Easement with group selection & 1 & 0.65 & 0.2 & 0.15 \\
Easement with group selection & 2 & 0.3 & 0.7 & 0 \\
Easement with shelterwood & 1 & 0.8 & 0.15 & 0.05 \\
Easement with shelterwood & 2 & 0.4 & 0.6 & 0 \\
Sell 5 acres, remainder & 1 & 0.9 & 0.1 & 0 \\
personal use & & & & 0 \\
Sell 5 acres, remainder & 2 & 0.65 & 0.35 & 0 \\
personal use & & & & \\
\hline
\end{tabular}


Table A8.13

\begin{tabular}{lcccc}
\hline \hline & Expert & $\begin{array}{c}\text { Less } \\
\text { conservation } \\
\text { value for } \\
\text { herps }\end{array}$ & $\begin{array}{c}\text { Equal } \\
\text { conservation } \\
\text { value for } \\
\text { herps }\end{array}$ & $\begin{array}{c}\text { More } \\
\text { conservation } \\
\text { value for } \\
\text { herps }\end{array}$ \\
\hline No modification & 1 & 0 & 1 & 0 \\
No modification & 2 & 0 & 1 & 0 \\
Personal use & 1 & 0 & 1 & 0 \\
Personal use & 2 & 0.15 & 0.82 & 0.03 \\
Thinning & 1 & 0.1 & 0.8 & 0.1 \\
Thinning & 2 & 0.3 & 0.5 & 0.2 \\
Group selection & 1 & 0.5 & 0.45 & 0.05 \\
Group selection & 2 & 0.2 & 0.5 & 0.3 \\
Shelterwood & 1 & 0.9 & 0.1 & 0 \\
Shelterwood & 2 & 0.5 & 0.05 & 0.45 \\
Easement with no modification & 1 & 0 & 1 & 0 \\
Easement with no modification & 2 & 0 & 1 & 0 \\
Easement with personal use & 1 & 0 & 1 & 0 \\
Easement with personal use & 2 & 0.15 & 0.82 & 0.03 \\
Easement with thinning & 1 & 0.1 & 0.8 & 0.1 \\
Easement with thinning & 2 & 0.3 & 0.5 & 0.2 \\
Easement with group selection & 1 & 0.5 & 0.45 & 0.05 \\
Easement with group selection & 2 & 0.2 & 0.5 & 0.3 \\
Easement with shelterwood & 1 & 0.9 & 0.1 & 0 \\
Easement with shelterwood & 2 & 0.5 & 0.05 & 0.45 \\
Sell 5 acres, remainder personal & & & & 0.9 \\
use & 1 & 0.1 & 0.9 & 0 \\
Sell 5 acres, remainder personal & & & & 0.05 \\
use & 2 & 0.5 & 0.45 & 0.05 \\
\hline
\end{tabular}


Table A8.14

\begin{tabular}{lccc}
\hline \hline Decision option & $\begin{array}{c}\text { Lower } \\
\text { abundance of } \\
\text { shade- } \\
\text { intolerant trees }\end{array}$ & $\begin{array}{c}\text { Equal } \\
\text { abundance of } \\
\text { shade- } \\
\text { intolerant trees }\end{array}$ & $\begin{array}{c}\text { Greater } \\
\text { abundance of } \\
\text { shade- } \\
\text { intolerant trees }\end{array}$ \\
\hline Personal use & 0 & 1 & 0 \\
Thinning & 0.33 & 0.34 & 0.33 \\
Group selection & 0.1 & 0.6 & 0.3 \\
Shelterwood & 0.1 & 0.1 & 0.8 \\
Easement with no modification & 0.1 & 0.1 & 0.8 \\
Easement with personal use & 0 & 1 & 0 \\
Easement with thinning & 0.33 & 0.34 & 0.33 \\
Easement with group selection & 0.1 & 0.6 & 0.3 \\
Easement with shelterwood & 0.1 & 0.1 & 0.8 \\
Sell 5 acres, remainder personal & 0.1 & 0.1 & 0.8 \\
use & & & 0.33 \\
\hline
\end{tabular}


Table A8.15

Series 1

\begin{tabular}{|c|c|c|c|c|c|c|}
\hline Trees & Herps & Birds & $\begin{array}{c}\text { Very } \\
\text { high } \\
\text { native } \\
\text { diversity }\end{array}$ & $\begin{array}{c}\text { Moderately } \\
\text { high native } \\
\text { diversity }\end{array}$ & $\begin{array}{c}\text { Moderately } \\
\text { low native } \\
\text { diversity }\end{array}$ & $\begin{array}{l}\text { Very low } \\
\text { native } \\
\text { diversity }\end{array}$ \\
\hline $\begin{array}{l}\text { Less } \\
\text { shade- } \\
\text { intolerant }\end{array}$ & $\begin{array}{l}\text { Less } \\
\text { conservation } \\
\text { value }\end{array}$ & $\begin{array}{l}\text { Less } \\
\text { conservation } \\
\text { value }\end{array}$ & 0 & 0.33 & 0.34 & 0.33 \\
\hline $\begin{array}{l}\text { Less } \\
\text { shade- } \\
\text { intolerant }\end{array}$ & $\begin{array}{l}\text { Less } \\
\text { conservation } \\
\text { value }\end{array}$ & $\begin{array}{l}\text { Equal } \\
\text { conservation } \\
\text { value }\end{array}$ & 0.17 & 0.39 & 0.23 & 0.22 \\
\hline $\begin{array}{l}\text { Less } \\
\text { shade- } \\
\text { intolerant }\end{array}$ & $\begin{array}{l}\text { Less } \\
\text { conservation } \\
\text { value }\end{array}$ & $\begin{array}{l}\text { More } \\
\text { conservation } \\
\text { value }\end{array}$ & 0.25 & 0.30 & 0.23 & 0.22 \\
\hline $\begin{array}{l}\text { Less } \\
\text { shade- } \\
\text { intolerant }\end{array}$ & $\begin{array}{l}\text { Equal } \\
\text { conservation } \\
\text { value }\end{array}$ & $\begin{array}{l}\text { Less } \\
\text { conservation } \\
\text { value }\end{array}$ & 0.17 & 0.39 & 0.23 & 0.22 \\
\hline $\begin{array}{l}\text { Less } \\
\text { shade- } \\
\text { intolerant }\end{array}$ & $\begin{array}{l}\text { Equal } \\
\text { conservation } \\
\text { value }\end{array}$ & $\begin{array}{l}\text { Equal } \\
\text { conservation } \\
\text { value }\end{array}$ & 0.33 & 0.44 & 0.11 & 0.11 \\
\hline $\begin{array}{l}\text { Less } \\
\text { shade- } \\
\text { intolerant }\end{array}$ & $\begin{array}{l}\text { Equal } \\
\text { conservation } \\
\text { value }\end{array}$ & $\begin{array}{l}\text { More } \\
\text { conservation } \\
\text { value }\end{array}$ & 0.42 & 0.36 & 0.11 & 0.11 \\
\hline $\begin{array}{l}\text { Less } \\
\text { shade- } \\
\text { intolerant }\end{array}$ & $\begin{array}{l}\text { More } \\
\text { conservation } \\
\text { value }\end{array}$ & $\begin{array}{l}\text { Less } \\
\text { conservation } \\
\text { value }\end{array}$ & 0.25 & 0.30 & 0.23 & 0.22 \\
\hline $\begin{array}{l}\text { Less } \\
\text { shade- } \\
\text { intolerant }\end{array}$ & $\begin{array}{l}\text { More } \\
\text { conservation } \\
\text { value }\end{array}$ & $\begin{array}{l}\text { Equal } \\
\text { conservation } \\
\text { value }\end{array}$ & 0.42 & 0.36 & 0.11 & 0.11 \\
\hline $\begin{array}{l}\text { Less } \\
\text { shade- } \\
\text { intolerant }\end{array}$ & $\begin{array}{l}\text { More } \\
\text { conservation } \\
\text { value }\end{array}$ & $\begin{array}{l}\text { More } \\
\text { conservation } \\
\text { value }\end{array}$ & 0.50 & 0.28 & 0.11 & 0.11 \\
\hline
\end{tabular}




\begin{tabular}{|c|c|c|c|c|c|c|}
\hline Equal & $\begin{array}{l}\text { Less } \\
\text { conservation } \\
\text { value }\end{array}$ & $\begin{array}{l}\text { Less } \\
\text { conservation } \\
\text { value }\end{array}$ & 0.17 & 0.39 & 0.23 & 0.22 \\
\hline Equal & $\begin{array}{l}\text { Less } \\
\text { conservation } \\
\text { value } \\
\text { Less } \\
\text { conservation }\end{array}$ & $\begin{array}{l}\text { Equal } \\
\text { conservation } \\
\text { value } \\
\text { More } \\
\text { conservation }\end{array}$ & 0.33 & 0.44 & 0.11 & 0.11 \\
\hline Equal & value & value & 0.42 & 0.36 & 0.11 & 0.11 \\
\hline Equal & $\begin{array}{l}\text { Equal } \\
\text { conservation } \\
\text { value }\end{array}$ & $\begin{array}{l}\text { Less } \\
\text { conservation } \\
\text { value }\end{array}$ & 0.33 & 0.44 & 0.11 & 0.11 \\
\hline Equal & $\begin{array}{l}\text { Equal } \\
\text { conservation } \\
\text { value }\end{array}$ & $\begin{array}{l}\text { Equal } \\
\text { conservation } \\
\text { value }\end{array}$ & 0.50 & 0.50 & 0 & 0 \\
\hline Equal & $\begin{array}{l}\text { Equal } \\
\text { conservation } \\
\text { value }\end{array}$ & $\begin{array}{l}\text { More } \\
\text { conservation } \\
\text { value }\end{array}$ & 0.58 & 0.42 & 0 & 0 \\
\hline Equal & $\begin{array}{l}\text { More } \\
\text { conservation } \\
\text { value }\end{array}$ & $\begin{array}{l}\text { Less } \\
\text { conservation } \\
\text { value }\end{array}$ & 0.42 & 0.36 & 0.11 & 0.11 \\
\hline Equal & $\begin{array}{l}\text { More } \\
\text { conservation } \\
\text { value }\end{array}$ & $\begin{array}{l}\text { Equal } \\
\text { conservation } \\
\text { value }\end{array}$ & 0.58 & 0.42 & 0 & 0 \\
\hline Equal & $\begin{array}{l}\text { More } \\
\text { conservation } \\
\text { value }\end{array}$ & $\begin{array}{l}\text { More } \\
\text { conservation } \\
\text { value }\end{array}$ & 0.67 & 0.33 & 0 & 0 \\
\hline $\begin{array}{l}\text { More } \\
\text { shade- } \\
\text { intolerant }\end{array}$ & $\begin{array}{l}\text { Less } \\
\text { conservation } \\
\text { value }\end{array}$ & $\begin{array}{l}\text { Less } \\
\text { conservation } \\
\text { value }\end{array}$ & 0.25 & 0.30 & 0.23 & 0.22 \\
\hline $\begin{array}{l}\text { More } \\
\text { shade- } \\
\text { intolerant }\end{array}$ & $\begin{array}{l}\text { Less } \\
\text { conservation } \\
\text { value }\end{array}$ & $\begin{array}{l}\text { Equal } \\
\text { conservation } \\
\text { value }\end{array}$ & 0.42 & 0.36 & 0.11 & 0.11 \\
\hline
\end{tabular}




\begin{tabular}{|c|c|c|c|c|c|c|}
\hline $\begin{array}{l}\text { More } \\
\text { shade- } \\
\text { intolerant }\end{array}$ & $\begin{array}{l}\text { Less } \\
\text { conservation } \\
\text { value }\end{array}$ & $\begin{array}{l}\text { More } \\
\text { conservation } \\
\text { value }\end{array}$ & 0.50 & 0.28 & 0.11 & 0.11 \\
\hline $\begin{array}{l}\text { More } \\
\text { shade- } \\
\text { intolerant }\end{array}$ & $\begin{array}{l}\text { Equal } \\
\text { conservation } \\
\text { value }\end{array}$ & $\begin{array}{l}\text { Less } \\
\text { conservation } \\
\text { value }\end{array}$ & 0.42 & 0.36 & 0.11 & 0.11 \\
\hline $\begin{array}{l}\text { More } \\
\text { shade- } \\
\text { intolerant } \\
\text { More } \\
\text { shade- } \\
\text { intolerant }\end{array}$ & $\begin{array}{l}\text { Equal } \\
\text { conservation } \\
\text { value } \\
\text { Equal } \\
\text { conservation } \\
\text { value }\end{array}$ & $\begin{array}{l}\text { Equal } \\
\text { conservation } \\
\text { value } \\
\text { More } \\
\text { conservation } \\
\text { value }\end{array}$ & 0.58 & 0.42 & 0 & 0 \\
\hline $\begin{array}{l}\text { More } \\
\text { shade- } \\
\text { intolerant }\end{array}$ & $\begin{array}{l}\text { More } \\
\text { conservation } \\
\text { value }\end{array}$ & $\begin{array}{l}\text { Less } \\
\text { conservation } \\
\text { value }\end{array}$ & 0.50 & 0.28 & 0.11 & 0.11 \\
\hline $\begin{array}{l}\text { More } \\
\text { shade- } \\
\text { intolerant }\end{array}$ & $\begin{array}{l}\text { More } \\
\text { conservation } \\
\text { value }\end{array}$ & $\begin{array}{l}\text { Equal } \\
\text { conservation } \\
\text { value }\end{array}$ & 0.67 & 0.33 & 0 & 0 \\
\hline $\begin{array}{l}\text { More } \\
\text { shade- } \\
\text { intolerant }\end{array}$ & $\begin{array}{l}\text { More } \\
\text { conservation } \\
\text { value }\end{array}$ & $\begin{array}{l}\text { More } \\
\text { conservation } \\
\text { value }\end{array}$ & 0.75 & 0.25 & 0 & 0 \\
\hline
\end{tabular}


Series 2

\begin{tabular}{|c|c|c|c|c|}
\hline Trees & Herps & Birds & $\begin{array}{c}\text { High } \\
\text { native } \\
\text { diversity }\end{array}$ & $\begin{array}{c}\text { Low } \\
\text { native } \\
\text { diversity }\end{array}$ \\
\hline $\begin{array}{l}\text { Less shade- } \\
\text { intolerant }\end{array}$ & Less conservation value & Less conservation value & 0.33 & 0.67 \\
\hline $\begin{array}{l}\text { Less snade- } \\
\text { intolerant }\end{array}$ & Less conservation value & Equal conservation value & 0.55 & 0.45 \\
\hline Less shade- & & & & \\
\hline intolerant & Less conservation value & More conservation value & 0.55 & 0.45 \\
\hline intolerant & Equal conservation value & Less conservation value & 0.55 & 0.45 \\
\hline intolerant & Equal conservation value & Equal conservation value & 0.78 & 0.22 \\
\hline Less shade- & & & & \\
\hline $\begin{array}{l}\text { Intolerant } \\
\text { Less shade- }\end{array}$ & Equal conservation value & More conservation value & 0.78 & 0.22 \\
\hline intolerant & More conservation value & Less conservation value & 0.55 & 0.45 \\
\hline intolerant & More conservation value & Equal conservation value & 0.78 & 0.22 \\
\hline $\begin{array}{l}\text { Less shade- } \\
\text { intolerant }\end{array}$ & More conservation value & More conservation value & 0.78 & 0.22 \\
\hline Equal & Less conservation value & Less conservation value & 0.55 & 0.45 \\
\hline Equal & Less conservation value & Equal conservation value & 0.78 & 0.22 \\
\hline Equal & Less conservation value & More conservation value & 0.78 & 0.22 \\
\hline Equal & Equal conservation value & Less conservation value & 0.78 & 0.22 \\
\hline Equal & Equal conservation value & Equal conservation value & 1 & 0 \\
\hline Equal & Equal conservation value & More conservation value & 1 & 0 \\
\hline Equal & More conservation value & Less conservation value & 0.78 & 0.22 \\
\hline Equal & More conservation value & Equal conservation value & 1 & 0 \\
\hline $\begin{array}{l}\text { Equal } \\
\text { More shade- }\end{array}$ & More conservation value & More conservation value & 1 & 0 \\
\hline $\begin{array}{l}\text { intolerant } \\
\text { More shade- }\end{array}$ & Less conservation value & Less conservation value & 0.55 & 0.45 \\
\hline $\begin{array}{l}\text { intolerant } \\
\text { More shade- }\end{array}$ & Less conservation value & Equal conservation value & 0.78 & 0.22 \\
\hline intolerant & Less conservation value & More conservation value & 0.78 & 0.22 \\
\hline $\begin{array}{l}\text { intolerant } \\
\text { More shade- }\end{array}$ & Equal conservation value & Less conservation value & 0.78 & 0.22 \\
\hline intolerant & Equal conservation value & Equal conservation value & 1 & 0 \\
\hline $\begin{array}{l}\text { intolerant } \\
\text { More shade- }\end{array}$ & Equal conservation value & More conservation value & 1 & 0 \\
\hline intolerant & More conservation value & Less conservation value & 0.78 & 0.22 \\
\hline
\end{tabular}


More shade-

intolerant

More shade-

intolerant

More conservation value

Equal conservation value

1

0

More conservation value More conservation value

1

0

Table A8.16

\begin{tabular}{|c|c|c|c|c|}
\hline & $\begin{array}{l}\text { Very high } \\
\text { native } \\
\text { species } \\
\text { diversity }\end{array}$ & $\begin{array}{c}\text { Moderately high } \\
\text { native species } \\
\text { diversity }\end{array}$ & $\begin{array}{c}\text { Moderately low } \\
\text { native species } \\
\text { diversity }\end{array}$ & $\begin{array}{l}\text { Very low } \\
\text { native } \\
\text { species } \\
\text { diversity }\end{array}$ \\
\hline $\begin{array}{l}\text { Less conservation value, } \\
\text { Lower shade-intolerant } \\
\text { tree abundance } \\
\text { Equal conservation } \\
\text { value, } \\
\text { Equal shade-intolerant } \\
\text { tree abundance } \\
\text { Greater conservation } \\
\text { value, } \\
\text { Greater shade-intolerant } \\
\text { tree abundance }\end{array}$ & 0.75 & 0.33 & 0.34 & 0.33 \\
\hline
\end{tabular}




\section{Appendix 9}

Financial information about the decision options. Twenty owners of large, forested properties (at least 20 ha in total area with at least 4 ha of forest) in Macon County, North Carolina, participated in a structured decision making (SDM) process consisting of two series of workshops with ten landowners each. In each series, landowners evaluated what they can do to their forest to maximize the achievement of their land use objectives. Landowners identified forest management decision options that could help achieve their objectives, and the expected utility of these decision options were evaluated for an average large, private forest (30 ha property with 22 ha of forest) in Macon County, North Carolina. Described here are expected financial figures for an average large, private forest in Macon County. This information was provided by Forest Stewards, the Land Trust for the Little Tennessee, and the Macon County tax assessor and was used to evaluate the decision options since one of the landowners' objectives was to maximize net income.

- At market value

○ Value of $\$ 819,537.60$ ( $\$ 27,317.92$ per ha)

○ Property taxes $=2,286.51$ dollars/year $* 30$ years $=\$ 68,595$

- Timber harvest

○ Expenses

- Create forest management plan $=\$ 1,087.26$

- Update forest management plan twice in 30 years $=\$ 1,087.26$

- Timber sale administration once $=\$ 4,756.77$

- Income

- Property tax $=30.17$ dollars/year *30 years $=\$ 904.99$

- Crown-thinning $=\$ 9,513.55$

- Group selection $=\$ 12,231.71$

- Shelterwood $=\$ 17,668.02$

- Conservation easement

$\circ$ Stewardship and legal defense fund

- Timber harvest $=\$ 10,250$

- No timber harvest $=\$ 5,000$

- Survey $=\$ 6,000$

- Baseline documentation report $=\$ 2,500$

○ Attorney and closing costs $=\$ 1,500$

- Property tax

- $\quad$ Timber harvest $=\$ 904.99$

- No timber harvest $=$ Depends on assessment but generally $50-80 \%$ reduction in property value, so assume $65 \%$ reduction $=\$ 24,008.37$

- Sell 1 ha

○ $\quad$ Sell price $=\$ 27,317.92$

- Taxes on 29 ha $=\$ 66,308.82$

- Variable expenses involved in finding buyer and finalizing sale 


\section{Appendix 10}

Completing the decision network. Twenty owners of large, forested properties (at least 20 ha in total area with at least 4 ha of forest) in Macon County, North Carolina, participated in a structured decision making (SDM) process consisting of two series of workshops with ten landowners each. In each series, landowners evaluated what they can do to their forest to maximize the achievement of their land use objectives. We built a Bayesian decision network to evaluate the expected utility of each decision option that could help landowners achieve their land use objectives. Described here are some procedures we used to analyze the Bayesian decision network.

For the water quality, exotic species abundance, and native species diversity nodes, Series 1 identified three levels in the attribute scale while Series 2 identified two levels. Experts were asked to provide probabilities for three levels, and we converted the probabilities to two levels by dividing the probability assigned to the second level in a three-level scale between the levels in a two-level scale. However, if the probability for the first or third level in a three-level scale was zero or one, we kept that probability and calculated the probability for the remaining level.

We calculated conditional probabilities for the native species diversity node by assigning probabilities for attribute levels when the forest was of less, equal, or more conservation value compared to an untouched forest for birds and herpetofauna. It is challenging to describe the response of taxa because different species have different niches. Total abundance of birds or herpetofauna is not adequate because it does not convey whether there are many individuals of a few generalist species or individuals from many species. Species richness indicates the total number of species but does not indicate information about the size of populations. Species evenness is not appropriate because there is no expectation about how similar population sizes should be among species. Therefore, we quantified the response of wildlife taxa to forests in terms of conservation value. In general, a conservation value index is a weighted sum of species' abundance (Götmark et al. 1986, Nuttle et al. 2003, Twedt 2005). The weight scales the abundance according to the species' conservation priority. We did not ask experts to complete any calculations, but rather to conceptualize their probabilities with regards to the forest's conservation value for birds or herpetofauna. We also assigned probabilities for attribute levels when the forest had lower, equal, or greater abundance of shade-intolerant trees compared to an untouched forest. Then, the probabilities for birds, herpetofauna, and shade-intolerant trees were averaged corresponding to each outcome combination. We first calculated probabilities for the four-level attribute scale for Series 1 and converted the probabilities for the two-level attribute for Series 2 by summing the Series 1 probabilities for the very high and moderately high levels and summing the Series 1 probabilities for the moderately low and very low levels.

At the time that landowners completed the conditional probability tables, we had not finalized the decision to include shelterwood harvest as a decision option. Landowners had said they were not interested in clearcutting, presumably because of aesthetics and a notion that clearcutting is bad for the environment, so we did not consider clearcutting and initially did not give much attention to shelterwood harvest. However, discussions with an expert at Forest Stewards and the consideration of shade-intolerant tree abundance led us to include shelterwood harvests in the decision options. Consequently, probabilities had not been completed for the effects of shelterwood harvests on rural landscapes in the Series 1 decision network. Therefore, we filled in probabilities that were consistent with the other probabilities in this node and asked 
landowners for revisions at the fourth workshop, but landowners did not request changes. Similarly, selling 1 ha was not included in the decision options when we asked the expert to provide conditional probabilities related to shade-tree abundance. We generated probabilities by multiplying the probabilities of each attribute level given personal use by 0.95 , calculated the mean probabilities for each attribute level by averaging across the decision options that had unique probabilities provided by the expert, multiplied each mean probability by 0.05 , and added the weighted mean probability for each attribute level and the corresponding weighted personal use probability.

An expert from the Land Trust for the Little Tennessee (LTLT) and an expert from Forest Stewards provided conditional probabilities for levels of net income given decision options. However, the LTLT may not have direct experience with the finances of timber harvests and Forest Stewards may not have specific information about conservation easement finances. Therefore, we talked to Forest Stewards about the costs and revenue associated with crown thinning, group selection, and shelterwood harvests and to the LTLT about the costs of conservation easements with and without timber harvest. We also discussed how property taxes would be affected by various decision options with Forest Stewards, the LTLT, and the Macon County tax assessor. For this analysis, we did not consider effects on income tax or estate tax because they are very landowner-specific, and this project focused on an evaluation of an average large, forested property in Macon County. After we compiled financial estimates from the experts (Appendix 9), we generated conditional probabilities for levels of net income given decision options and weighted them equally with the two sets of conditional probabilities from the LTLT and Forest Stewards. Based on the information provided by the LTLT and Forest Stewards, we also determined that a landowner would not be able to earn more than $33 \%$ of their income from the forest, making the node describing the proportion of income derived from the property deterministic.

Götmark, F., M. Ǻhlund, and M. O. G. Eriksson. 1986. Are indices reliable for assessing conservation value of natural areas? an avian case study. Biological Conservation 38: 5573.

Nuttle, T., A. Leidolf, and L. W. Burger Jr. 2003. Assessing conservation value of bird communities with partners in flight-based ranks. The Auk 120(1): 541-549.

Twedt, D. J. 2005. An objective method to determine an area's relative significance for avian conservation. USDA Forest Service General Technical Report PSW-GTR-191. 


\section{Appendix 11}

Utility values calculated in Bayesian decision networks. Twenty owners of large, forested properties (at least 20 ha in total area with at least 4 ha of forest) in Macon County, North Carolina, participated in a structured decision making (SDM) process consisting of two series of workshops $(\mathrm{a}=$ Series $1, \mathrm{~b}=$ Series 2$)$ with ten landowners each. In each series, landowners evaluated what they can do to their forest to maximize the achievement of their land use objectives. Utility values indicate the relative suitability of decision options by combining the probability of outcomes and the landowners' satisfaction with outcomes. Utility values were calculated using all combinations of objective weights and attribute scores, resulting in four scenarios for Series 1 and 24 scenarios for Series 2

(Appendices 5 and 6). Scenario 1 uses the mean objective weight and mean attribute score combinations. Personal use of the forest could involve harvesting firewood or using recreational trails. The three commercial harvesting methods (thinning, group selection, and shelterwood) would occur through the Present-Use Value program (Appendix 7). The no modification, personal use, and commercial harvesting decision options could also be combined with having a conservation easement (Appendix 7).

Table A11.1

a)

\begin{tabular}{lcccc}
\hline Decision options & Scenario 1 & Scenario 2 & Scenario 3 & Scenario 4 \\
\hline No modification & 65.39 & 81.99 & 56.88 & 76.16 \\
Personal use & 63.50 & 80.55 & 54.67 & 74.72 \\
Thinning & 72.62 & 84.09 & 62.61 & 79.68 \\
Group selection & 71.61 & 82.44 & 60.94 & 78.66 \\
Shelterwood & 72.84 & 82.38 & 62.25 & 79.39 \\
Easement with no modification & 65.39 & 81.99 & 56.88 & 76.16 \\
Easement with personal use & 63.76 & 80.74 & 54.85 & 74.87 \\
Easement with thinning & 70.14 & 82.97 & 60.39 & 78.31 \\
Easement with group selection & 69.88 & 81.63 & 59.67 & 77.89 \\
Easement with shelterwood & 71.62 & 81.79 & 61.44 & 78.90 \\
Sell 1 ha, remainder personal use & 68.21 & 77.70 & 58.21 & 76.32 \\
\hline
\end{tabular}


b)

\begin{tabular}{lccccc}
\hline Decision options & Scenario 1 & Scenario 2 & Scenario 3 & Scenario 4 & Scenario 5 \\
\hline No modification & 62.05 & 37.30 & 52.42 & 49.14 & 48.27 \\
Personal use & 58.44 & 34.71 & 48.76 & 46.20 & 46.29 \\
Thinning & 63.40 & 38.34 & 51.52 & 48.25 & 53.00 \\
Group selection & 59.20 & 34.69 & 45.67 & 43.47 & 51.34 \\
Shelterwood & 57.96 & 33.82 & 43.82 & 41.97 & 51.45 \\
Easement with no modification & 62.05 & 37.30 & 52.42 & 49.14 & 48.27 \\
Easement with personal use & 58.44 & 34.71 & 48.76 & 46.20 & 46.29 \\
Easement with thinning & 61.81 & 37.18 & 50.44 & 47.42 & 51.15 \\
Easement with group selection & 57.84 & 33.84 & 44.85 & 42.80 & 49.76 \\
Easement with shelterwood & 56.91 & 33.19 & 43.19 & 41.46 & 50.22 \\
Sell 1 ha, remainder personal use & 54.61 & 33.00 & 42.08 & 39.67 & 51.00 \\
\hline & & & & & \\
\hline \hline Decision options & Scenario 6 & Scenario 7 & Scenario 8 & Scenario 9 & Scenario 10 \\
\hline No modification & 54.60 & 59.66 & 64.34 & 50.18 & 63.23 \\
Personal use & 52.08 & 56.41 & 61.40 & 47.16 & 59.59 \\
Thinning & 57.62 & 60.36 & 63.43 & 61.69 & 70.12 \\
Group selection & 54.89 & 56.05 & 59.31 & 60.07 & 66.79 \\
Shelterwood & 54.76 & 54.85 & 58.05 & 61.21 & 66.23 \\
Easement with no modification & 54.60 & 59.66 & 64.34 & 50.18 & 63.23 \\
Easement with personal use & 52.08 & 56.41 & 61.40 & 47.16 & 59.59 \\
Easement with thinning & 56.02 & 59.08 & 62.62 & 57.80 & 67.11 \\
Easement with group selection & 53.76 & 55.12 & 58.71 & 56.75 & 64.02 \\
Easement with shelterwood & 53.94 & 54.17 & 57.60 & 58.65 & 64.04 \\
Sell 1 ha, remainder personal use & 53.32 & 53.14 & 54.94 & 60.64 & 63.72 \\
\hline
\end{tabular}




\begin{tabular}{lccccc}
\hline \hline Decision options & Scenario 11 & Scenario 12 & Scenario 13 & Scenario 14 & Scenario 15 \\
\hline No modification & 70.49 & 69.60 & 44.82 & 59.88 & 67.22 \\
Personal use & 65.85 & 65.42 & 41.91 & 56.28 & 62.57 \\
Thinning & 73.03 & 70.00 & 55.88 & 61.86 & 66.36 \\
Group selection & 67.19 & 64.48 & 54.26 & 57.60 & 59.85 \\
Shelterwood & 65.15 & 62.69 & 55.28 & 56.57 & 57.51 \\
Easement with no modification & 70.49 & 69.60 & 44.82 & 59.88 & 67.22 \\
Easement with personal use & 65.85 & 65.42 & 41.91 & 56.28 & 62.57 \\
Easement with thinning & 70.78 & 68.43 & 52.13 & 60.13 & 64.98 \\
Easement with group selection & 65.11 & 63.06 & 51.05 & 56.24 & 58.74 \\
Easement with shelterwood & 63.50 & 61.57 & 52.80 & 55.56 & 56.66 \\
Sell 1 ha, remainder personal use & 62.33 & 58.47 & 54.68 & 54.49 & 54.91 \\
\hline & & & & & \\
\hline Decision options & Scenario 16 & Scenario 17 & Scenario 18 & Scenario 19 & Scenario 20 \\
\hline No modification & 65.87 & 46.30 & 51.32 & 61.16 & 61.61 \\
Personal use & 61.66 & 43.70 & 47.92 & 56.58 & 57.55 \\
Thinning & 64.37 & 56.65 & 57.64 & 63.56 & 61.58 \\
Group selection & 58.46 & 55.17 & 54.35 & 57.69 & 56.07 \\
Shelterwood & 56.49 & 55.95 & 55.38 & 56.86 & 54.78 \\
Easement with no modification & 65.87 & 46.30 & 51.32 & 61.16 & 61.61 \\
Easement with personal use & 61.66 & 43.70 & 47.92 & 56.58 & 57.55 \\
Easement with thinning & 63.26 & 53.18 & 55.01 & 61.46 & 60.20 \\
Easement with group selection & 57.55 & 52.15 & 52.95 & 56.49 & 55.18 \\
Easement with shelterwood & 55.80 & 53.60 & 54.52 & 56.08 & 54.17 \\
Sell 1 ha, remainder personal use & 52.21 & 55.26 & 54.65 & 55.18 & 51.11 \\
\hline
\end{tabular}




\begin{tabular}{lcccc}
\hline \hline Decision options & Scenario 21 & Scenario 22 & Scenario 23 & Scenario 24 \\
\hline No modification & 49.32 & 56.64 & 60.69 & 41.05 \\
Personal use & 46.87 & 53.48 & 56.73 & 38.45 \\
Thinning & 59.01 & 65.89 & 65.21 & 50.61 \\
Group selection & 57.80 & 63.45 & 60.90 & 48.98 \\
Shelterwood & 58.81 & 63.86 & 59.80 & 49.61 \\
Easement with no modification & 49.32 & 56.64 & 60.69 & 41.05 \\
Easement with personal use & 46.87 & 53.48 & 56.73 & 38.45 \\
Easement with thinning & 55.77 & 62.34 & 62.73 & 47.34 \\
Easement with group selection & 55.03 & 60.59 & 58.76 & 46.13 \\
Easement with shelterwood & 56.68 & 61.65 & 58.15 & 47.40 \\
Sell 1 ha, remainder personal use & 58.37 & 61.90 & 57.72 & 48.92 \\
\hline
\end{tabular}




\section{Appendix 12}

Literature related to conditional probabilities. Twenty owners of large, forested properties (at least 20 ha in total area with at least 4 ha of forest) in Macon County, North Carolina, participated in a structured decision making (SDM) process consisting of two series of workshops with ten landowners each. In each series, landowners evaluated what they can do to their forest to maximize the achievement of their land use objectives. Forest management decision options were evaluated through a decision network that predicted expected outcomes from each decision option. Conditional probabilities describing the probability of outcomes given states were required to analyze the decision network. Here we describe literature supporting the conditional probabilities used in our decision network.

Although we were not able to obtain conditional probabilities directly from the scientific literature, patterns indicated in the literature were consistent with the conditional probabilities we gathered from experts. For example, fire risk is very low in the southern Appalachian region (Lafon et al. 2005, Fowler and Konopik 2007). The erosion risk tends to increase when more trees are removed, but erosion risk is low if forest cover is high (Montgomery et al. 2000, Hood et al. 2002, Dhakal and Sidle 2003, Miller and Burnett 2007). Similarly, water quality is high if the forest cover is high, but as more trees are removed, water quality tends to decrease (Aust and Blinn 2004, Stednick et al. 2004). Also, the abundance of exotic species appears to increase as the intensity of the forest use increases (Belote et al. 2008, Burnham and Lee 2010). The effects of disturbance on the conservation value of the forest for birds (Norris et al. 2009, Twedt and Somershoe 2009) and herpetofauna (Semlitsch et al. 2009, Strojny and Hunter 2010, Tilghman et al. 2012, Hocking et al. 2013) may be variable, but generally, the conservation value is expected to decrease as disturbance increases. While the effects of disturbance on the abundance of shadeintolerant trees may be variable also, abundance typically increases with disturbance that opens increasing amounts of canopy cover (LeDoux 1999, Webster and Lorimer 2005, Richards and Hart 2011, Lhotka 2013).

Aust, W. M. and C. R. Blinn. 2004. Forestry best management practices for timber harvesting and site preparation in the eastern United States: an overview of water quality and productivity research during the past 20 years (1982-2002). Water, Air, and Soil Pollution: Focus 4: 5-36.

Belote, R. T., R. H. Jones, S. M. Hood, and B. W. Wender. 2008. Diversity-invasibility across an experimental disturbance gradient in Appalachian forests. Ecology 89:183-192.

Burnham, K. M. and T. D. Lee. 2010. Canopy gaps facilitate establishment, growth, and reproduction of invasive Frangula alnus in a Tsuga canadensis dominated forest. Biological Invasions 12: 1509-1520.

Dhakal, A. S. and R. C. Sidle. 2003. Long-term modelling of landslides for different forest management practices. Earth Surface Processes and Landforms 28: 853-868.

Fowler, C. and E. Konopik. 2007. The history of fire in the southern United States. Human Ecology Review 14(2): 165-176. 
Hocking, D. J., K. J. Babbitt, and M. Yamasaki. 2013. Comparison of silvicultural and natural disturbance effects on terrestrial salamanders in northern hardwood forests. Biological Conservation 167: 194-202.

Hood, S. M., S. M. Zedaker, W. M. Aust, and D. W. Smith. 2002. Universal soil loss equation (USLE) - predicted soil loss for harvesting regimes in Appalachian hardwoods. Northern Journal of Applied Forestry 19(2): 53-58.

Lafon, C. W., J. A. Hoss, and H. D. Grissino-Mayer. 2005. The contemporary fire regime of the central Appalachian Mountains and its relation to climate. Physical Geography 26(2): 126-146.

LeDoux, C. B. 1999. An integrated approach for determining the size of hardwood groupselection openings. Forest Products Journal 49(3): 34-37.

Lhotka, J. M. 2013. Effect of gap size on mid-rotation stand structure and species composition in a naturally regenerated mixed broadleaf forest. New Forests 44: 311-325.

Miller, D. J. and K. M. Burnett. 2007. Effects of forest cover, topography, and sampling extent on the measured density of shallow, translational landslides. Water Resources Research 43(3): W03433.

Montgomery, D. R., K. M. Schmidt, H. M. Greenberg, and W. E. Dietrich. 2000. Forest clearing and regional landsliding. Geology 28(4): 311-314.

Norris, J. L., M. J. Chamberlain, and D. J. Twedt. 2009. Effects of wildlife forestry on abundance of breeding birds in bottomland hardwood forests of Louisiana. The Journal of Wildlife Management 73(8): 1368-1379.

Richards, J. D. and J. L. Hart. 2011. Canopy gap dynamics and development patterns in secondary Quercus stands on the Cumberland Plateau, Alabama, USA. Forest Ecology and Management 262: 2229-2239.

Semlitsch, R. D., B. D. Todd, S. M. Blomquist, A. J. K. Calhoun, J. W. Gibbons, J. P. Gibbs, G. J. Graeter, E. B. Harper, D. J. Hocking, M. L. Hunter Jr., D. A. Patrick, T. A. G. Rittenhouse, and B. B. Rothermel. 2009. Effects of timber harvest on amphibian populations: understanding mechanisms from forest experiments. BioScience 59(10): 853-862.

Stednick, J. D., C. A. Troendle and G. G. Ice. 2004. Lessons for watershed research in the future. In G. G. Ice and J. D. Stednick (eds) A century of forest and wildland watershed lessons. Society of American Foresters, Bethesda, MD, USA.

Strojny, C. A. and M. L. Hunter Jr. 2010. Relative abundance of amphibians in forest canopy gaps of natural origin vs. timber harvest origin. Animal Biodiversity and Conservation 33(1): 1-13.

Tilghman, J., S. W. Ramee, and D. M. Marsh. 2012. Meta-analysis of the effects of canopy removal on terrestrial salamander populations in North America. Biological Conservation 152:1-9.

Twedt, D. J. and S. G. Somershoe. 2009. Bird response to prescribed silvicultural treatments in bottomland hardwood forests. Journal of Wildlife Management 73: 1140-1150.

Webster, C. R. and C. G. Lorimer. 2005. Minimum opening sizes for canopy recruitment of midtolerant tree species: a retrospective approach. Ecological Applications 15(4): 12451262. 
